\title{
New national and regional bryophyte records, 63
}

L. T. Ellis, O. M. Afonina, I. V. Czernyadjeva, L. A. Konoreva, A. D. Potemkin, V. M. Kotkova, M. Alataş, H. H. Blom, M. Boiko, R. A. Cabral, S. Jimenez, D. Dagnino, C. Turcato, L. Minuto, P. Erzberger, T. Ezer, O. V. Galanina, N. Hodgetts, M. S. Ignatov, A. Ignatova, S. G. Kazanovsky, T. Kiebacher, H. Köckinger, E. O. Korolkova, J. Larraín, A. I. Maksimov, D. Maity, A. Martins, M. Sim-Sim, F. Monteiro, L. Catarino, R. Medina, M. Nobis, A. Nowak, R. Ochyra, I. Parnikoza, V. Ivanets, V. Plášek, M. Philippe, P. Saha, Md. N. Aziz, A. V. Shkurko, S. Ştefănuţ, G. M. Suárez, A. Uygur, K. Erkul, M. Wierzgoń \& A. Graulich

To cite this article: L. T. Ellis, O. M. Afonina, I. V. Czernyadjeva, L. A. Konoreva, A. D. Potemkin, V. M. Kotkova, M. Alataș, H. H. Blom, M. Boiko, R. A. Cabral, S. Jimenez, D. Dagnino, C. Turcato, L. Minuto, P. Erzberger, T. Ezer, O. V. Galanina, N. Hodgetts, M. S. Ignatov, A. Ignatova, S. G. Kazanovsky, T. Kiebacher, H. Köckinger, E. O. Korolkova, J. Larraín, A. I. Maksimov, D. Maity, A. Martins, M. Sim-Sim, F. Monteiro, L. Catarino, R. Medina, M. Nobis, A. Nowak, R. Ochyra, I. Parnikoza, V. Ivanets, V. Plášek, M. Philippe, P. Saha, Md. N. Aziz, A. V. Shkurko, S. Ștefănuț, G. M. Suárez, A. Uygur, K. Erkul, M. Wierzgoń \& A. Graulich (2020): New national and regional bryophyte records, 63, Journal of Bryology, DOI: 10.1080/03736687.2020.1750930

To link to this article: https://doi.org/10.1080/03736687.2020.1750930 


\section{New national and regional bryophyte records, 63}

L. T. Ellis ${ }^{a}$, O. M. Afonina ${ }^{b}$, I. V. Czernyadjeva ${ }^{b}$, L. A. Konoreva ${ }^{b}$, A. D. Potemkin ${ }^{b}$, V. M. Kotkova ${ }^{b}$, M. Alataş $^{c}$, H. H. Blom ${ }^{d}$, M. Boiko ${ }^{e}$, R. A. Cabral ${ }^{f}$, S. Jimenez ${ }^{f}$ D. Dagnino ${ }^{g}$, C. Turcato $^{g}$, L. Minuto ${ }^{g}$, P. Erzberger ${ }^{h}$, T. Ezer $^{i, j}$, O. V. Galanina ${ }^{k, b}$, N. Hodgetts', M. S. Ignatov ${ }^{m, n}$, A. Ignatovan ${ }^{n}$, S. G. Kazanovsky ${ }^{\circ}$, T. Kiebacher ${ }^{p}$, H. Köckinger $^{q}$,

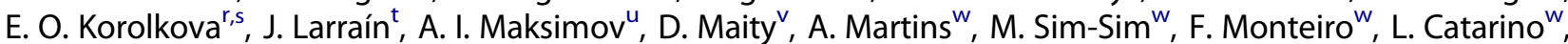

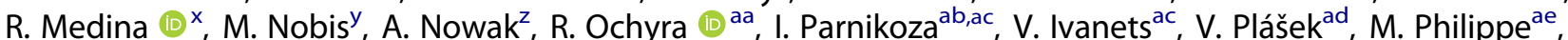
P. Saha ${ }^{\text {af }}$, Md. N. Aziz $^{\text {af }}$, A. V. Shkurko ${ }^{\text {ag }}$, S. Ştefănuț ${ }^{\text {ah }}$, G. M. Suárez ${ }^{\text {ai,aj }}$, A. Uygur ${ }^{\text {aj }}$, K. Erkul $^{\text {ak }}$, M. Wierzgoń $^{\text {al }}$ and A. Graulich ${ }^{\text {am }}$

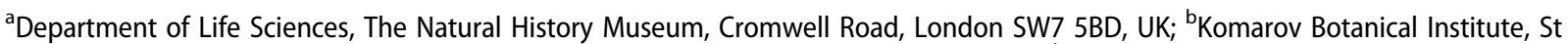

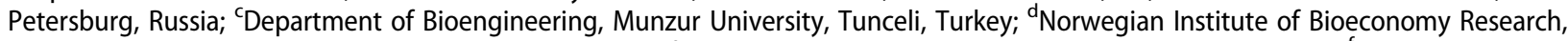
Division of Forest and Forest Resources, Bergen, Norway; ${ }^{e}$ Department of Botany, Kherson State University, Ukraine; ${ }^{f}$ Instituto de Botánica del Nordeste, Corrientes, Argentina; ${ }^{9}$ Department of Earth, Environment and Life Sciences (DISTAV), University of Genoa, Genoa, Italy; hBerlin, Germany; 'Department of Biology, Niğde Ömer Halisdemir University, Niğde, Turkey; 'Department of Landscape Architecture, Niğde

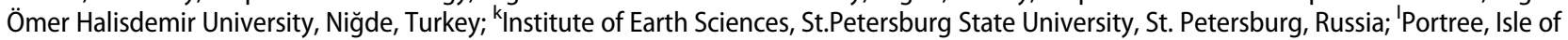
Skye, UK; ${ }^{\mathrm{m}}$ Tsitsin Main Botanical Garden, Moscow, Russia; ${ }^{\mathrm{n}}$ Faculty of Biology, Moscow State University, Moscow, Russia; ${ }^{\circ}$ Siberian Branch of the Russian Academy of Sciences, Siberian Institute of Plant Physiology \& Biochemistry, Irkutsk, Russia; ${ }^{\mathrm{P}}$ Department of Systematic and

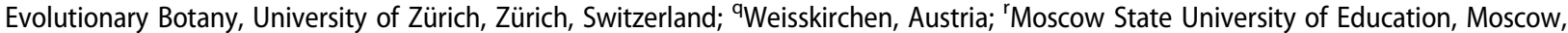
Russia; ${ }^{5}$ National Research University Higher School of Economics, Moscow, Russia; Instituto de Biología, Pontificia Universidad Católica de Valparaíso, Valparaíso, Chile; "Institute of Biology of Karelian Research Centre of Russian Academy of Sciences, Petrozavodsk, Russia; ${ }^{\top}$ Taxonomy and Biosystematics Laboratory, Department of Botany, University of Calcutta, Kolkata, India; ${ }^{\mathrm{w}} \mathrm{CE} 3 \mathrm{c}$, Centre for Ecology, Evolution and Environmental Changes, Universidade de Lisboa, Faculdade de Ciências de Lisboa, Lisboa, Portugal; ${ }^{\text {X} A u g u s t a n a ~ C o l l e g e, ~ R o c k ~ I s l a n d, ~}$ Illinois, USA; ${ }^{y}$ Jagiellonian University, Kraków, Poland; ${ }^{\mathrm{Z}}$ University of Opole, Opole, Poland; ${ }^{\text {aa } W . ~ S z a f e r ~ I n s t i t u t e ~ o f ~ B o t a n y, ~ P o l i s h ~ A c a d e m y ~ o f ~}$

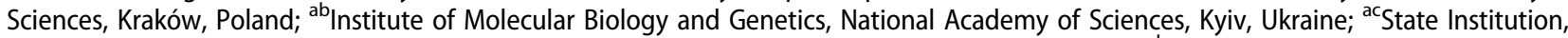
National Antarctic Scientific Centre, Ministry of Education and Science of the Ukraine, Kyiv, Ukraine; ad Department of Biology and Ecology University of Ostrava, Ostrava, Czech Republic; ae Université Lyon-1 et UMR CNRS 5023 "Ecologie des Hydrosystèmes Naturels et

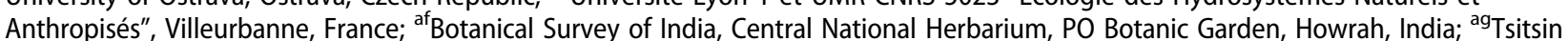

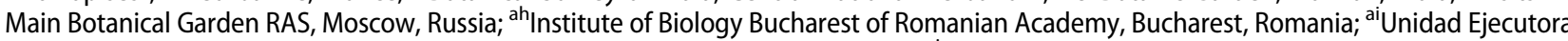
Lillo (UEL; FML-CONICET), Miguel Lillo 251, S.M. de Tucumán (4000), Argentina; ${ }^{a}$ Facultad de Ciencias Naturales e Instituto Miguel Lillo,

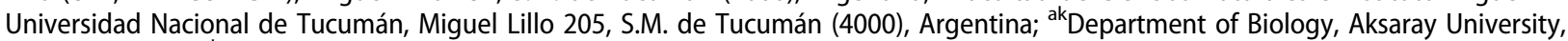

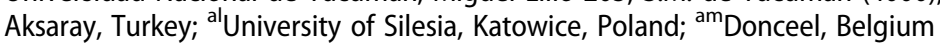

\section{Bucklandiella subsecunda (Harv.) Bedn.-Ochyra \& Ochyra}

\section{Contributor. R. Ochyra}

Madagascar. Diana Region, Tsaratanana Massif, $14^{\circ}$ 01'S, 48 56'W, 1200-2400 m a.s.l., April 1924, leg. Perrier de la Bathe s.n. (H-Brotherus, JE-Herzog, PCP.de la Varde 0707821, PC-Thériot 0708099).

Racomitrium Brid., in its traditional circumscription is poorly represented in the moss flora of Madagascar and hitherto only one specimen of this genus has been discovered on this fourth largest island in the world. It was collected in 1924 by Perrier de la Bathie on the Tsaratanana Massif, and Thériot (1926) reported it as an unnamed form of Racomitrium lepervanchei Besch., a species endemic to Réunion Island. As Racomitrium proved to be heterogeneous, it was split into six segregates (Ochyra, Żarnowiec et al. 2003; Bednarek-Ochyra, Ochyra, Sawicki et al. 2014; Bednarek-Ochyra, Sawicki, Ochyra, et al. 2015; Sawicki et al. 2015), R. lepervanchei was placed in the genus Bucklandiella Roiv. Nevertheless, the voucher specimen was not studied by De Sloover
(1977) in his survey of African Racomitrium and this material was assigned either to $R$. crispulum (Hook.f. \& Wilson) Wilson (Crosby et al. 1983) or Bucklandiella membranacea (Mitt.) Bedn.-Ochyra \& Ochyra (Marline et al. 2012), as R. lepervanchei was considered to be conspecific with these species (Clifford 1955; Lawton 1973). The specimen from the Tsaratanana Massif has distinct auricles and broad, flattened costa with 6-8 enlarged ventral guide cells, which are typical of Bucklandiella subsecunda. This is a pantropical oreophyte, widespread in tropical and subtropical Asia (Frisvoll 1988), subSaharan Africa (Bednarek-Ochyra and Ochyra 2012a, 2013; Ochyra and van Rooy 2013), Central and South America (Bednarek-Ochyra et al. 1999; Bednarek-Ochyra and Ochyra 2012b; Ellis, Bakalin et al. 2013) and the maritime Antarctic (Ochyra, Lewis Smith et al. 2008).

\section{Calymperes afzelii Sw.}

Contributors. A. Martins, N. Hodgetts, F. Monteiro, L. Catarino and M. Sim-Sim 
Republic of Guinea-Bissau. Bijagós Archipelago, Marine National Park of João Vieira Poilão, Cavalos Island, $11.011528^{\circ} \mathrm{N} 15.708694^{\circ} \mathrm{W}$, ca. $20 \mathrm{~m}$ a.s.l., on trunk of Sterculia tragacantha Lindl., 11 July 2016, leg. L. Catarino \& B. Indjai s.n. (LISU).

Calymperes afzelii is known from Mexico, the West Indies, Central and South America, Asia, Africa, the Indian Ocean islands, the Pacific islands and Australia (Reese 2007).

Calymperes afzelli from Guinea-Bissau exhibits leaves bordered by a polystratose marginal rib, which in the chlorophyllose limb, incorporates stereids. In the leaf base the hyaline lamina is bordered by a narrow intramarginal rib of thick-walled linear cells. The marginal ribs in the chlorophyllose limb are denticulate and/or dentate. The modified apices of gemmiferous leaves are narrow and parallel-sided, running to a rounded tip (Ellis 2018).

This species was collected from the trunk of Sterculia tragacantha in a palm grove.

\section{Calymperes erosum Müll.Hal.}

Contributors. A. Martins, N. Hodgetts, F. Monteiro, L. Catarino and M. Sim-Sim

Republic of Guinea-Bissau. Bijagós Archipelago: (1) Bolama Island, Bolama village, $11.3430^{\circ} \mathrm{N}, 15.2904^{\circ} \mathrm{W}$, $25 \mathrm{~m}$ a.s.l., on trunk of Faidherbia albida (Delile) A.Chev., 26 October 2018, leg. F. Monteiro s.n. (LISU); (2) Marine National Park of João Vieira Poilão, Meio Island, $11.033611^{\circ} \mathrm{N}, 15.623861^{\circ} \mathrm{W}$, ca. $15 \mathrm{~m}$ a.s.l., on trunk of Elaeis guineensis Jacq., 6 July 2016, leg. L. Catarino \& B. Indjai s.n. (LISU); (3) Marine National Park of João Vieira Poilão, Meio Island, $11.989806^{\circ} \mathrm{N}$ $15.671917^{\circ} \mathrm{W}$, ca. $17 \mathrm{~m}$ a.s.l., on trunk of Elaeis guineensis, 6 July 2016, leg. L. Catarino \& B. Indjai s.n. (LISU); (4) Marine National Park of João Vieira Poilão, Cavalos Island, $11.022167^{\circ} \mathrm{N} 15.710750^{\circ} \mathrm{W}$, ca. $15 \mathrm{~m}$ a.s.l., on trunk of Elaeis guineensis, 11 July 2016, leg. L. Catarino \& B. Indjai s.n. (LISU).

Calymperes erosum occurs in Florida (USA), Mexico, the Caribbean, Central and South America, Asia, Africa, some Atlantic islands, some Indian Ocean islands, some Pacific islands, Australia (Reese 2007), and Italy (Pantelleria) (Brullo et al. 2001). The specimens identified from Guinea-Bissau have leaves bordered by an intramarginal rib extending from the base to near the apex, which in the chlorophyllose limb, incorporates stereids. At the apex of the hyaline lamina, the hyaline cells become acutely protuberant and overlap adjacent cells in the chlorophyllose lamina (Ellis 2018).

On Bolama Island, $C$. erosum grew on the trunk of Faidherbia albida in an open forest. In the Marine National Park of João Vieira Poilão, this species was recorded on Meio and Cavalos Islands, growing on the trunk of the palm-tree Elaeis guineensis in a dense forest.
4. Calymperes pallidum Mitt.

Contributors. A. Martins, N. Hodgetts, F. Monteiro, L. Catarino and M. Sim-Sim

Republic of Guinea-Bissau. Bijagós Archipelago, Bolama Island, Granja do Estado, $11.558912^{\circ} \mathrm{N}$, $15.471169^{\circ} \mathrm{W}, 21 \mathrm{~m}$ a.s.l., on a cashew (Anacardium occidentale L.) trunk during the rainy season, 27 October 2018, leg. F. Monteiro s.n. (LISU).

Calymperes pallidum has been recorded from the West Indies, South America, Africa and Asia (Reese 2007), and is characterised by the lack of stereids in the costa (Ellis 2018). On Bolama, this species grows in a habitat dominated by cashew trees (95\%) with few native plant species, belonging to a cashew orchard promoted by the Ministry of Agriculture of Guinea-Bissau.

\section{Calymperes tenerum Müll.Hal.}

Contributors. A. Martins, N. Hodgetts, F. Monteiro, L. Catarino and M. Sim-Sim

Republic of Guinea-Bissau. Bijagós Archipelago, Marine National Park of João Vieira Poilão, Cavalos Island, $11.022167^{\circ} \mathrm{N}, 15.710750^{\circ} \mathrm{W}$, ca. $15 \mathrm{~m}$ a.s.l., on trunk of Spondias mombin L., 11 July 2016, leg. L. Catarino \& B. Indjai s.n. (LISU).

Calymperes tenerum occurs in Mexico, the West Indies, South America (southern Brazil), Asia, Africa, the Indian Ocean islands, the Pacific islands and Australia (Reese 2007). Leaves in C. tenerum have an excurrent costa, and in the leaf base, the hyaline lamina is bordered by a broad band of quadrate to shortly subrectangular cells with thickened angles (Ellis 2018). On Cavalos Island this species was collected in a palm grove from the trunk of Spondias mombin.

\section{Campylopus subulatus Schimp. ex Milde} Contributors. D. Dagnino, C. Turcato and L. Minuto Italy. Liguria Region, Beigua Regional Natural Park, Mt. Beigua, Prariondo, Pian Fretto, $1064 \mathrm{~m}$ a.s.l. $44^{\circ}$ 25"52.46"N, 8³6'3.31"E, 11 November 2017, leg. D. Dagnino s.n., det. D. Dagnino \& C. Turcato (GE B138).

This is the first record of Campylopus subulatus for the Liguria Region. This circumpolar species shows a fragmented distribution within both boreal and tropical mountains (Dierßen 2001), and it is rare in the Mediterranean Basin where it is known only from Italy, Spain, Portugal, France, Serbia and Slovenia (and other few countries with single records; Ros et al. 2013). In Italy C. subulatus has been reported only in four administrative regions (i.e. Piemonte, Toscana, Trentino Alto Adige and Lombardia; Aleffi et al. 2008) and was recently discovered in the Marche Region (Tacchi et al. 2009).

Campylopus subulatus was found on small serpentinite outcrops occupied by a discontinuous plant community, with a paucispecific contingent of phanerogams dominated by succulent chamaephytes 
and therophytes (referring to the Sedo-Scleranthetalia order) and a richer contingent of bryophytes including Racomitrium elongatum (Ehrh.) ex Frisvoll, Hypnum callichroum Brid., Ceratodon purpureus (Hedw.) Brid., Grimmia donniana Sm., Dicranum scoparium Hedw. and Bryum Hedw. spp. These outcrops occur in a marshy area, mainly characterised by mountain grasslands and beech forests growing under a sub-oceanic climate.

7. Dichodontium flavescens (Dicks. ex With.) Lindb. Contributor. A. Graulich

Corsica. Corse du Sud, Bocognano, Busso, wet rocks along the Gravona river, associated with Lejeunea lamacerina (Steph.) Schiffn. and Plagiochila asplenioides (L.) Dumort., $42^{\circ} 05^{\prime} 32^{\prime \prime} \mathrm{N}, 9^{\circ} 03^{\prime} 34^{\prime \prime} \mathrm{E}, 510 \mathrm{~m}$ a.s.l., 07 July 2018, leg. A. Graulich s.n., det. A. Graulich \& A. Vanderpoorten, (Herb. Graulich Corsica 31/18).

This is the first report from Corsica for D. flavescens, and it is largely unrecorded around most of the Mediterranean basin. However, its distribution area is poorly known (Ros et al. 2013), because the relevant vegetative features that distinguish it from the similar D. pellucidum (Hedw.) Schimp. were described only relatively recently (Werner 2002).

\section{Ditrichum heteromallum (Hedw.) Britt.}

\section{Contributors. P. Saha, Md. N. Aziz and D. Maity}

India. West Bengal: Darjeeling, Kalimpong, Rishop, growing on soil with Pogonatum neesii (Müll.Hal.) Dozy, $27^{\circ} 06^{\prime} 13.90^{\prime \prime} \mathrm{N}, 88^{\circ} 39^{\prime} 05.65^{\prime \prime} \mathrm{E}, 2179 \mathrm{~m}$ a.s.l., 13 June 2013, leg. Pamela Saha 64602a (CAL).

The genus Ditrichum Timm. ex Hampe has 69 species worldwide (Crosby et al. 1999) and Lal (2005) reported 12 species from India, distributed in the Eastern and Western Himalayas as well as South India. Gangulee (1971) recorded six species and two infraspecific taxa from the Darjeeling district.

The plants were small, yellowish-green with sparsely branched stems. The leaves were slightly homomallous, appressed when dry, lanceolate, abruptly narrowed to a long subula, with the costa filling almost the entire subula; leaf margins were plane and entire, and leaf cells linear. The capsule was erect, cylindrical with linear peristome teeth, divided from the middle.

Ditrichum heteromallum has been found in some areas in Arunachal Pradesh (Eastern Himalaya), Uttarakhand (Western Himalaya) and Uttar Pradesh, and is recorded for the first time from Darjeeling Himalaya in West Bengal.

\section{Ditrichum tortuloides Grout}

\section{Contributors. P. Saha, Md. N. Aziz and D. Maity}

India. West Bengal: Darjeeling, Kalimpong, Lava, growing on soil, $27^{\circ} 05^{\prime} 11.82^{\prime \prime} \mathrm{N}, 088^{\circ} 39^{\prime} 39.93^{\prime \prime} \mathrm{E}$, $2060 \mathrm{~m}$ a.s.l., 10 June 2013, leg. Pamela Saha 64559 (CAL).
Ditrichum tortuloides is known from Meghalaya in the Eastern Himalaya and Uttarakhand in Western Himalaya. The species is here recorded for the first time from the Darjeeling Himalaya in West Bengal. Plants in the new collection can be described as follows: shoots small, yellowish-brown; stems simple; leaves appressed to stem when dry, lanceolate, leaf apex gradually narrowed to a subula, margins strongly toothed above, but mostly entire, sometimes recurved below; leaf base broadly triangular; lamina cells elongate-rhomboid, becoming quadrate towards margin.

\section{Dryptodon austrofunalis (Müll.Hal.) Ochyra \&} Żarnowiec

Contributors. R. Ochyra and V. Plášek

Chile. Provincia Coyhaique, XI Región de Aisén del General Carlos Ibáñez del Campo: (1) El Maqui (El Chacon) on Río Toqui, $7 \mathrm{~km}$ to the east of Santa Magda and about $65 \mathrm{~km}$ north of Coyhaique by Ruta $\mathrm{X}-421$ from Lago Pedro A. Cerda to El Maqui, $45^{\circ}$ $00^{\prime} 53^{\prime \prime} \mathrm{S}, 71^{\circ} 59^{\prime} 08^{\prime \prime} \mathrm{W}, 535 \mathrm{~m}$ a.s.l., on dry and exposed boulder growing together with Bucklandiella didyma (Mont.) Bedn.-Ochyra \& Ochyra, 20 January 2015, leg. H. Bednarek-Ochyra \& R. Ochyra 896/15 with V. Plášek (KRAM B-245695, SGO); (2) Laguna Bravo by Ruta X423 about $3 \mathrm{~km}$ before El Gato and about $65 \mathrm{~km}$ north of Coyhaique, $45^{\circ} 05^{\prime} 26^{\prime \prime} \mathrm{S}, 71^{\circ} 51^{\prime} 12^{\prime \prime} \mathrm{W}, 815 \mathrm{~m}$ a.s.l., on dry boulders associated with Schistidium Bruch \& Schimp. sp., 20 January 2015, leg. H. Bednarek-Ochyra \& R. Ochyra 949A/15 with V. Plášek (KRAM B-245709); (3) same locality, on dry boulders in a thin plantation of pines, associated with Bucklandiella striatipila (Cardot) Bedn.-Ochyra \& Ochyra and B. didyma, 10 January 2015, leg. H. Bednarek-Ochyra \& R. Ochyra 946/15 with V. Plášek (KRAM B-245708); (4) northern end of Lago Castor about $20 \mathrm{~km}$ east of Coyhaique at Ruta X-667, 45 $35^{\prime} 40^{\prime \prime} \mathrm{S}, 71^{\circ} 47^{\prime} 39^{\prime \prime} \mathrm{W}, 797 \mathrm{~m}$ a.s.l., on dry and exposed rock, 22 January 2015, leg. H. Bednarek-Ochyra \& R. Ochyra 1000/15 \& 1001/15 with V. Plášek (KRAM B245722 \& B-245725, SGO); (5) Large rock west of Los Huemules opposite the small peninsula on the northern shore of Lago Atrovesado at Ruta X-608 from Coyhaique to Lago Portales, $20 \mathrm{~km}$ south-west of Coyhaique, $45^{\circ} 41^{\prime} 22^{\prime \prime} \mathrm{S}, 72^{\circ} 16^{\prime} 57^{\prime \prime} \mathrm{W}, 370-380 \mathrm{~m}$ a.s.l., on very large stone covered with a carpet of Bucklandiella striatipila forming quite large patches in dry and exposed sites, associated with B. stritipila, B. didyma and Acroschisma wilsonii (Hook.f.) Lindl., 18 January 2015, leg. H. Bednarek-Ochyra \& R. Ochyra 710/15, $712 / 15,721 / 15$ \& 722/12 with V. Plášek (KRAM B245624, B-245625, B-245629 \& B-245630, SGO).

Dryptodon austrofunalis is the largest representative of the genus in South America, usually imitating racomitrialean mosses by having sinuose laminal cells. However, it is easily known by its costal anatomy and 
frequent formation of multicellular stalked gemmae on the dorsal side of the proximal part of the costa. The species is widely scattered in the Andes from southern Chile to Venezuela (Muñoz 1999). Its distribution in Chile is still inadequately known and it was recorded only from some stations in the Regións of O'Higgins, La Araucanía and Los Lagos (Muñoz 1999) and Maule, Bío-Bío and Aisén, largely without indication of the sources (Müller 2009). Recently, the species was reported from Última Esperanza Province in the Región Magallanes (Larraín and Bahamonde 2017) and Capitán Prat Province in the Región Aisén (Larraín 2016), as well as from all provinces in the Región Bío-Bío (Ireland et al. 2017). Herein, $D$. austrofunalis is recorded from Coyhaique Province in the Aisén Región where it occurs in abundance. Dryptodon austrofunalis was originally described from Australia, and it is widely distributed in Australasia. It had also been reported from Europe (Ireland, Scotland, England, Greece) (Greven 1997), but these records proved be incorrect and actually refer to various other species of Dryptodon Brid. (Maier 2010). Thus, $D$. austrofunalis has to be considered a south-amphipacific-temperate species. This is a relatively rare distribution pattern, exhibited only by a small group of austral mosses (Ochyra and Lewis Smith 1998; Bednarek-Ochyra and Ochyra 2011; Ochyra, Crabtree et al. 2015).

\section{Ectropothecium cyperoides (Hook.) A.Jaeger} Contributors. P. Saha, Md. N. Aziz and D. Maity

India. West Bengal: Darjeeling, Kalimpong, Lava, growing on rock in association with Thuidium cymbifo-

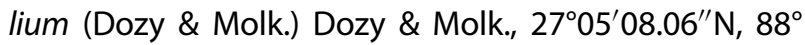
$39^{\prime} 47.76^{\prime \prime} \mathrm{E}, 2040 \mathrm{~m}$ a.s.l., 10 June 2013, leg. Pamela Saha $64555 b(\mathrm{CAL})$.

Worldwide, Ectropothecium M.Fleisch. is represented by 203 species (Crosby et al. 1999), of which 12 occur in India. These are mostly distributed in the Eastern Himalaya, and restricted in Western Himalaya and South India (Lal 2005). Gangulee (1980) reported five species from the Darjeeling district.

The plants were glossy, yellowish-green with ovate-lanceolate, falcate, concave, leaves. These had a double costa, linear-rhomboidal lamina cells, and alar cells not well differentiated, with only a few inflated, rectangular cells present at the basal angles. The leaf margins were serrate above and in places, irregularly recurved.

Ectropothecium cyperoides is distributed in Arunachal Pradesh, Assam, Nagaland, Uttarakhand and South India. It is here recorded for the first time from Darjeeling Himalaya in West Bengal.

12. Fissidens celticus Paton

Contributors. A. Uygur, T. Ezer, S. K. Erkul and M. Alataş
Turkey. Mersin Province, Taşeli Plateau, Bozyazı District, Kömürler Village road: $36^{\circ} 8^{\prime} \mathrm{N}, 32^{\circ} 57^{\prime} \mathrm{E}$, growing on moist soil, $240 \mathrm{~m}$ a.s.l., 29 January 2019, leg. and det. T. Ezer, A. Uygur \& M. Alataş s.n. (A.U.324).

Fissidens celticus was identified among collections from the Bozyazı District in the southern part of the Taşeli Plateau (Mediterranean Region of Turkey, Mersin). It is an oceanic stenotopic species, reported here for the first time from Turkey and southwest Asia. Fissidens Hedw. has been represented by about 25 taxa in Turkey (Ezer 2016; Erdağ and Kürschner 2017). The latest taxonomic and distributional status of the species was determined by reference to Ros et al. (2013), and Erdağ and Kürschner (2017). This new record, F. celticus, brings the total to 26 taxa in Fissidens known from Turkey.

The species has been reported from several European localities: Britain and Ireland, Belgium, northern and western France, Italy (Sardinia), Spain (Iberian Peninsula), Switzerland, and western Germany (Vanderpoorten and Sotiaux 2002; Guerra et al. 2012; Ros et al. 2013; Hodgetts 2019). In addition, the species is included in the IUCN Red List of Threatened Species in the LC category (Hodgetts 2019).

Fissidens celticus is a European endemic moss, characterised by unbordered leaves, distinctly bent costa, and crenulate leaf margin (Vanderpoorten and Sotiaux 2002; Smith 2004). The present record of F. celticus from Anatolia is an important extension of range southwards. The region is characterised by a Mediterranean climate with mild wet winters and warm to hot, dry summers. The speciemens occurred on on moist calcareous soil together with Bartramia stricta Brid., Bryum dichotomum Hedw., Didymodon tophaceus (Brid.) Lisa, Targionia hypophylla L., and Timmiella barbuloides (Brid.) Mönk. The population was sterile, and therefore, sporophytes are unknown in Turkey.

\section{Fissidens submarginatus Bruch.}

Contributors. R. A. Cabral, S. Jimenez and G. M. Suárez Argentina. Corrientes Province: Reserva Natural Privada Paraje Tres Cerros, 29 $06^{\prime} 32.79^{\prime \prime} \mathrm{S}, 56^{\circ}$ 55'55.82"W, $175 \mathrm{~m}$ a.s.l., en suelo húmedo sobre la ladera Sur del cerro Nazareno, 16 April 2019, leg. R. A. Cabral 56 (CTES).

The Paraje Tres Cerros Private Nature Reserve (Corrientes, Argentina) was created to protect the unique landscape within Corrientes Province, with rocky outcrops of sandstones and basalts that protrude from the vast plain that surrounds them. The southern slopes are more pronounced and retain moisture, creating characteristic plant formations on the opposite side of the hills (e.g. gramineous shrub-steppe on the northern slope and hygrophilic forest on the southern slope) (Carnevali 1994). This phenomenon generates a great diversity 
of microhabitats (Cajade et al. 2013) suitable for bryophyte colonisation. Samples recently collected were processed according to the classic methodology for this group and deposited at CTES herbarium (Anderson 1954; Gradstein et al. 2001). One such sample was identified as Fissidens submarginatus Bruch, a species characterised by the presence of a vaginant lamina, not clasping the stem; limbidium present on all leaves, extending the entire length or nearly so of the vaginant laminae; laminal cells unipapillose, and costa percurrent or sub-percurrent ending one or two cells below the leaf apex (Pursell 2007).

Fissidens submarginatus inhabits soil, rock or termite mounds, and also at the bases of decomposing trunks and branches (Bordin and Yano 2013). In Argentina the species was found growing mixed with Lophocolea bidentata (L.) Dumort. and Lejeunea lepida Lindenb. \& Gottsche. Its distribution includes Africa and America, from United States to southern Paraguay and Brazil (Pursell 2007), and is here recorded for the first time for Argentina, representing its southernmost extent.

\section{Grimmia incurva Schwägr.}

\section{Contributor. A. Graulich}

Corsica. Haute-Corse, Vivario, Punta dell'Oriente, near the summit on the north face, on granite in a large crevice, $42^{\circ} 05^{\prime} 28^{\prime \prime} \mathrm{N}, 9^{\circ} 08^{\prime} 03^{\prime \prime} \mathrm{E}, 2090 \mathrm{~m}$ a.s.l., 13 July 2018, leg. A. Graulich s.n., det. A. Graulich \& A. Sotiaux, (Herb. Graulich Corsica17/18).

This alpine species is reported from Corsica for the first time. In Europe, Grimmia incurva is present in nearly every montane area (Smith 2004). Nevertheless this species has hitherto, never been reported from the Mediterranean islands (Ros et al. 2013).

\section{Hygrohypnum eugyrium (Schimp.) Broth.}

\section{Contributor. A. Graulich}

Corsica. Haute-Corse, Vivario, Vizzavona, near the cave of Southwell, on rocks flushed by a tributary (Ruisseau de Speloncello) of the Vecchio river, with Marsupella emarginata (Ehrh.) Dumort., Plagiomnium undulatum (Hedw.) T.J.Kop., Rhizomnium punctatum (Hedw.) T.J.Kop. and Thamnobryum alopecurum (Hedw.) Gangulee, $42^{\circ} 08^{\prime} 14^{\prime \prime} \mathrm{N}, 9^{\circ} 08^{\prime} 13^{\prime \prime} \mathrm{E}, 880 \mathrm{~m}$ a.s.l., 4 July 2018 , leg. A. Graulich, det. A. Graulich \& A. Vanderpoorten (Herb. Graulich Corsica 24/18).

In Corsica, the only record of this pleurocarpous moss dates back to 1902 . Indeed $H$. eugyrium was then reported from Aitone forest (Camus 1902). Since that report this species has never been reported from Corsica or from other Mediterranean islands (Ros et al. 2013).

16. Hyophila involuta (Hook.) A.Jaeger

Contributors. A. Martins, N. Hodgetts, F. Monteiro, L. Catarino and M. Sim-Sim
Republic of Guinea-Bissau. Bijagós Archipelago, Bolama Island, Ofir Beach, $11.3323^{\circ} \mathrm{N}, 15.2823^{\circ} \mathrm{W}, 8 \mathrm{~m}$ a.s.l., on artificial wall, 27 October 2018, leg. F. Monteiro s.n. (LISU).

Hyophila involuta has a pantropical distribution and is also known from Europe (Austria, Germany, France, Italy, Slovenia, Switzerland and Spain) (Eckel 2007; Hodgetts 2015). In Guinea-Bissau, H. involuta forms blackish green tufts, the leaves are lingulate with a broadly pointed apex. The upper leaf margins are denticulate and the lamina cells are mamillose on the ventral surface (Frey et al. 2006).

This species was found on an artificial wall at Ofir beach, where it is periodically exposed to sea water.

\section{Hypnum cupressiforme var. Iacunosum Brid. Contributor. A. Graulich}

Corsica. Corse du Sud, Bocognano, Busso, on boulders with Hedwigia ciliata (Hedw.) P.Beauv., Nogopterium gracile (Hedw.) Crosby \& W.R.Buck. [Pterogonium gracile (Hedw.) Sm.] and Racomitrium elongatum Frisvoll, $42^{\circ} 05^{\prime} 45^{\prime \prime} \mathrm{N}, 9^{\circ} 03^{\prime} 55^{\prime \prime} \mathrm{E}, 740 \mathrm{~m}$ a.s.l., 2 July 2018, leg. A. Graulich s.n., (Herb. Graulich Corsica25/18).

This is the first record from Corsica for this variety of Hypnum Hedw. that is widely distributed in the Mediterranean basin (Ros et al. 2013).

\section{Isopterygium albescens (Hook.) A.Jaeger}

Contributors. P. Saha, Md. N. Aziz and D. Maity

India. West Bengal: Darjeeling, Siliguri, Mahananda Wildlife Sanctuary, $26^{\circ} 53^{\prime} 25^{\prime \prime} \mathrm{N}, 8^{\circ} 23^{\prime} 57^{\prime \prime} \mathrm{E}, 1116 \mathrm{~m}$ a.s.l., 22 February 2014, leg. Pamela Saha 64724 (CAL).

Worldwide the genus Isopterygium Lindb. is represented by 150 species (Crosby et al. 1999); 21 of these are found in India, distributed both in the Eastern and Western Himalayas, and in southern India (Lal 2005). Gangulee (1980) recorded two species from the Darjeeling district. Isopterygium albescens is found in Arunachal Pradesh, Meghalaya, Sikkim, Assam Uttarakhand and Tamil Nadu, and is here recorded for the first time from the Darjeeling Himalaya in West Bengal. Plants in this new collection have: shoots slender, glossy, green; stems rounded in transverse section, central strand present, small; leaves ovate to ovate-lanceolate; apex gradually or suddenly acuminate; margins entire below, serrulate above; costa double, short or sometimes indistinct; leaf cells linear; cells of extreme base rectangular to sub-rectangular; alar cells not well differentiated, some irregular cells present in the alar region, not clearly distinct.

19. Leucobryum glaucum (Hedw.) Ångstr.

Contributor. M. Boiko

Ukraine. Steppe zone, Kherson region, Oleshky district, the village Chelburda. $46.611067^{\circ} \mathrm{N}, 32.892367^{\circ} \mathrm{E}$, in sparse pine plantation of Pinus sylvestris L. with Betula borysthenica Klok., in depression on damp sandy soil 
covered with pine needle remains, in association with the epigeneic species Dicranum scoparium Hedw., Hypnum cupressiforme Hedw., Brachythecium salebrosum (Hoffm. ex F.Weber \& Mohr) Schimp., Polytrichum piliferum Hedw. 20 October 2019, leg. V. Ishchenko s.n., det. M. Boiko (KHER).

Leucobryum glaucum is a large cushion forming, pannemoral, mezophytic, helio-sciophytic, acidophilic, dioecious, oligomezotrophic and coenotically inactive species. It forms whitish-green, domed cushions, up to $6-8 \mathrm{~cm}$ high and up to $10-15 \mathrm{~cm}$ wide. In the Ukraine it is known from several localities: Zakarpattya, Ukrayins'ki Karpaty, Prykarpattya, Poliss'ia (borealnemoral zone) and Lisostep, but only two specimens are known from the far east of the steppe zone of the Ukraine (Boiko 1992, 2008, 2009). A record of the species in the Autonomous Republic of the Crimea is very doubtful (Partyka 2005). The species is generally distributed in Europe, the Caucasus, North Africa, Asia, North and Central America, and Oceania (Boiko 2009; Ellis, Aleffi, Asthana et al. 2018). The new discovery is the first for the Black Sea lowland of the subzone of fescue-feather grass steppes of southern Ukraine. The closest known other location for this species is more than $300 \mathrm{~km}$ to the north, near Irdin' Marsh in the Cherkassy region (D. Zerov's finding). The moss L. glaucum is dioecious, and rarely develops sex organs and spore capsules. In the conditions prevailing in the Ukraine, it propagates vegetatively by fragmentation and by buds on rhizoidal protonema. Leucobryum glaucum belongs to the category of 'regionally rare' species in the steppe physical and geographical zone of the Ukraine, in particular for Kharkiv, Kherson and Lugans'k regions.

\section{Lophozia perssonii H.Buch \& S.W.Arnell}

Contributors. A. D. Potemkin and V. M. Kotkova

Russia. Pskov Region: Pechory District, Izborsk-Maly Valley, tuff outcrop, on hard tuff stones and projections, $57.72926^{\circ} \mathrm{N}, 27.84615^{\circ} \mathrm{E}, 72 \mathrm{~m}$ a.s.l., with gemmae and male plants, 10 September 2019, leg. V. M. Kotkova \& A. D. Potemkin s.n., det. A. D. Potemkin (LE).

Lophozia perssonii (三 Oleolophozia perssonii (H.Buch \& S.W.Arnell) L.Söderstr., De Roo \& Hedd.) is a rare and protected species in Russia (Red Data Book of Russian Federation 2008). In the adjacent Leningrad Region and St Petersburg it is also protected and occurs in similar habitats, on tuff outcrops, and tuff constructions, such as the bases of old, small bridges (Sofronova et al. 2015; Red Data Book of Leningrad Region 2018; Red Data Book of St. Petersburg 2018). The closest other location for this species is in the western part of Estonia where it grows on a sandstone cliff in Toriis. Lophozia perssonii has been monitored in Estonia since 2019 (Nele Ingerpuu, pers. com., 14 November 2019). It is protected in Estonia and has IUCN category CR based on criteria B2ab(iii) (Ingerpuu et al. 2018). This record of $L$. perssonii is the southernmost in European Russia.

\section{Orthotrichum pilosissimum R.Medina, F.Lara \&} Garilleti

\section{Contributor. R. Medina}

United States. Utah, Tooele Co., between Stockton and Rocky Peak, Soldier Creek, $40^{\circ} 25^{\prime} 43.5^{\prime \prime} \mathrm{N}, 112^{\circ}$ 16'50.2"W, $1919 \mathrm{~m}$ a.s.l., bark of Acer grandidentatum Nutt. $1 \mathrm{~m}$ from creek, 6 June 2019, leg. R. Medina $1713 a$ with A. Manteca (CONN, AUGIE).

This is the first record of Orthotrichum pilosissimum outside of Nevada, from where it was reported in six localities at the time of its description (Medina et al. 2011), plus a collection in 2015 (Churchill Co., leg. J. Nachlinger 3233, CAS). The new record represents a substantial expansion of the distribution range up to the eastern limit of the Great Basin Floristic Province. Three other collections in the east of Nevada, (R. Medina 1652, 1655a, 1656 with A. Manteca (CONN, AUGIE)), collected in May 2019, also indicate that the species is not restricted to the western half of the basin. These collections are morphologically consistent with the described specific variation, all of them showing the distinct tomentum on stems and leaf bases, interpreted as axillary hairs whose overdevelopment is not found in other mosses (Medina et al. 2011). The density of brood bodies is variable across colonies, being much higher in younger tufts without sporophytes. This suggests a reproductive strategy that combines asexual, short-distance, clonal propagation during early colonisation with longer-ranged spore dispersal once sexual reproduction has occurred (Kimmerer 1991). Orthotrichum pilosissimum is apparently an endemic of the Great Basin Floristic Province, colonising the creek valleys of mountain ranges dominated by pinyon-juniper woodlands between 1500 and $2300 \mathrm{~m}$ a.s.l. and growing on rocks and bark of different riverine phorophytes. Its presence in states within the same floristic province (adjacent regions of California, Oregon, and Idaho) is likely and a conservation status assessment for this scarcely known species will require further investigation.

\section{Orthotrichum scanicum Grönvall}

Contributors. V. Plášek, A. Nowak and M. Nobis

Tajikistan. $80 \mathrm{~km}$ ENE of Dushanbe capital city, N part of Obigarm town, NW edge of Sarykhorsky Nature Refuge, $38^{\circ} 43^{\prime} 14.6^{\prime \prime} \mathrm{N}, \quad 69^{\circ} 42^{\prime} 41.9^{\prime \prime} \mathrm{E} 1359 \mathrm{~m}$. a.s.l., along public road, on bark of shrub, 30 May 2011, leg. V. Plášek, s.n. with A. Nowak and M. Nobis (OSTR).

Until now, 18 species of orthotrichaceous mosses belonging to four genera (Sawicki, Plášek et al. 2017) have been reported from Tajikistan, including Orthotrichum Hedw. (11), Lewinskya F.Lara, Garilleti \& Goffinet (6), Nyholmiella Holmen \& E.Warncke (1), and Pulvigera Plášek, Sawicki \& Ochyra (1) (Mamatkulov et al. 1998; 
Ignatov et al. 2006; Blockeel et al. 2009; Ellis, Akhoondi Darzikolaei et al. 2011; Ellis, Alegro et al. 2012; Ellis, Aleffi, Tacchi et al. 2014; Ellis, Bayliss et al. 2014; Plášek et al. 2014). Herein, O. scanicum is added as a twelveth species of the genus to the moss flora of this country. It was first collected during a CzechPolish expedition in 2011, which yielded a number of interesting bryophyte records (cf. Číhal et al. 2017), including a discovery of a new species, O. pamiricum Plášek, Sawicki \& Číhal (Plášek et al. 2014). Orthotrichum scanicum grew on the branch of a mulberry shrub (Morus L. sp.) along a public road. The moss cushions were found at $1.5 \mathrm{~m}$ above the ground growing together with O. crenulatum Mitt. and Lewinskya speciosa (Nees) F.Lara, Garilleti \& Goffinet and richly producing sporophytes. As currently known, O. scanicum has a highly dissected panholarctic geographic range with maximum occurrence in Europe (cf. Skoupá et al. 2018). In Central Asia, the species was recently discovered also in Kyrgyzstan (Ellis et al. 2015), in western China (Skoupá et al. 2018) and one historical record is known also from Kazakhstan (Lewinsky-Haapasaari 1996).

\section{Philonotis yezoana Bisch \& Cardot}

Contributors. S. G. Kazanovsky and O. M. Afonina

Russia. Southern Siberia, Khamar-Daban Ridge, Republic of Buryatia, Kabansk District, Baikal State Nature Biosphere Reserve, upper course of Osinovka River, vicinity of scientific station 'Chum', 51 $31^{\prime} 22^{\prime \prime} \mathrm{N}, 105^{\circ} 22^{\prime} 33^{\prime \prime} \mathrm{E}$, $1035 \mathrm{~m}$ a.s.l., on wet stones along the stream, 30 July 1990, leg. S. G. Kazanovsky s.n., det. O. M. Afonina (LE).

Philonotis yezoana is an Asian-North American species with its predominant distribution along the northern part of the coast of the Pacific Ocean. In Asia the species is known from Japan and Korea, and records in China, according to Koponen and Ignatova (2018), require confirmation. In North America it is distributed from Alaska to California and has isolated localities in Vermont and Newfoundland.

In Russia this species was first reported from Kamchatka (Czernyadjeva 1995). However, Ochi (1962, 1963) previously reported a specimen as $P$. fontana var. seriata (Mitt.) Kindb. from the Kurils (Koponen et al. 2012). Later this species was found on Sakhalin (Cherdantseva et al. 2006), the Kuril Islands (Bakalin and Cherdantseva 2006; Cherdantseva 2006), and in Primorye (Gorobets and Smirnova 2004). It was recently reported in Finnish Lapland as a new species for Europe (Ulvinen and Kypärä 2016). The location of $P$. yezoana in southern Siberia (Buryatia) is significantly removed from its main range, and also from the site in Finnish Lapland where it is apparently a relict. Philonotis yezoana is easily recognised by the laminal cells with central papillae.

24. Pseudephemerum nitidum (Hedw.) Loeske Contributors. M. S. Ignatov, J. Larraín and E. A. Ignatova
Chile. Región de Los Ríos (XIV), Valdivia Province, along the road to Corral, pine plantation on slope to the river, meadow near the road, $25 \mathrm{~m}$ a.s.l., $39^{\circ} 57^{\prime} 0.9^{\prime \prime} \mathrm{S}, 73^{\circ}$ $18^{\prime} 51.6^{\prime \prime} \mathrm{W}, 11$ June 2019, leg. M. Ignatov \& E. Ignatova 19-37 p.p. (CONC, MHA).

This small cleistocarpic moss, described by Hedwig (1801) from Germany, is readily distinguished by the lax leaf areolation, denticulate leaf apex, and by the sporophytes appearing lateral along the stems due to subfloral innovations, sometimes more than one on a single stem. The studied specimen from Chile shows a typical morphology and matches in all traits with European material. The species is widely distributed in Europe, and also present in Macaronesia, Africa (Algeria, Morocco, Congo, Kenya, Rwanda, Zaire, Madagascar), Asia (Sri Lanka, Assam, Nepal, Japan), Tasmania, New Zealand, Mexico, and NW North America (Potier de la Varde 1955; Schofield 1968; De Sloover 1976; Smith 2004; Yip 2002, 2007). The species has seldom been collected in South America, known from only three other collections, two from Brazil and one from Colombia (da Silva and Peralta 2017). Iwatsuki (1980) suggests that this taxon might have been introduced in Japan, which might be also the case with the Chilean populations. Its habitat in Chile, loamy roadsides with numerous puddles, looks quite similar to habitats in e.g. European Russia.

\section{Racomitrium elongatum Ehrh. ex Frisvoll}

Contributors. D. Dagnino, C. Turcato and L. Minuto Italy. Liguria Region, Beigua Regional Natural Park: (1). Mt Beigua, Prariondo, Bric Sciue Gianche, $1161 \mathrm{~m}$ a.s.l., $44^{\circ} 26^{\prime} 14.78^{\prime \prime} \mathrm{N}, 8^{\circ} 36^{\prime} 47.34^{\prime \prime} \mathrm{E}, 11$ November 2017, leg. D. Dagnino s.n., det. D. Dagnino \& C. Turcato (GE B129). (2). Mt Beigua, Prariondo, Pian Fretto, $1074 \mathrm{~m}$

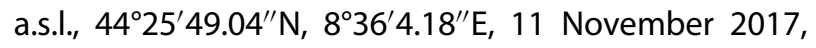
leg. D. Dagnino s.n., det. D. Dagnino \& C. Turcato (GE B130).

This is the first record of Racomitrium elongatum for the Liguria Region, although this Euro-North American species is known to occur in most of the northern Italian administrative regions (Aleffi et al. 2008). Racomitrium elongatum typically grows on acid rocks in mountain areas with an oceanic climate. The species was found on serpentinite outcrops within the Beigua Regional Natural Park, in a beech forest and in marshy mountain grassland. This area is characterised by a sub-oceanic climate very close to that of the Mediterranean.

26. Riccia huebeneriana Lindenb.

Contributor. S. Ştefănuț

Romania. Botoșani County: Horodiștea, Prut Valley, $48^{\circ}$ $15^{\prime} 25.3^{\prime \prime} \mathrm{N}, 26^{\circ} 42^{\prime} 20.0^{\prime \prime} \mathrm{E}, 104 \mathrm{~m}$ a.s.l., on sandy-clayey alluvial bank, 24 August 2019, leg. S. Ştefănuț s.n., det. S. Ştefănuţ (BUCA B4900). 
Riccia huebeneriana grew along with Marchantia polymorpha L., Pellia neesiana (Gottsche) Limpr. and Riccia frostii Austin. This is the first report of Riccia huebeneriana from Romania (Ştefănuț and Goia 2012). The conservation status of $R$. huebeneriana in Romania is Critically Endangered - CR B1ab(ii,iii) + 2ab(ii,iii).

27. Schistidium andreaeopsis (Müll.Hal.) Laz.

Contributors. I. V. Czernyadjeva and L. A. Konoreva

Russia. Franz Josef Land Archipelago: Ziegler Island, in the vicinity of Rods Strait, $3 \mathrm{~m}$ a. s. I., $80^{\circ} 52^{\prime} 28.4^{\prime \prime} \mathrm{N}, 57^{\circ}$ $17^{\prime} 17.6^{\prime \prime} \mathrm{E}$, near rookery, on soil in swampy Salix polarismoss-lichen tundra, with a small admixture of Pseudocalliergon brevifolium (Lindb.) Hedenäs, 25 July 2019, leg. L. A. Konoreva, \# 911 (LE).

This is the northernmost record of Schistidium andreaeopsis. This species is distributed in the Arctic and Subarctic of Asian Russia, on the Taimyr Peninsula, on the October Revolution and Bolshevik Islands of the Severnaya Zemlya Archipelago, on Wrangel Island and Chukotka; it is known from a few localities in the permafrost zone of Yakutia, in European Russia from the Novaya Zemlya Archipelago, and in North America from Prince Patrick and Ellef Ringnes Islands of the Canadian Arctic Archipelago (Afonina et al. 2005; Afonina 2015; Ignatova and Blom 2017). Although S. andreaeopsis was intentionally omitted from the Flora of North America, with the supposed North American records reported as S. holmenianum Steere \& Brassard (Mclntosh 2007), all North American specimens of $S$. andreaeopsis in LE, reported by Afonina et al. (2005) and Afonina (2015) from the Canadian Arctic Archipelago, represent typical S. andreaeopsis.

Schistidium andreaeopsis is characterised by plants relatively large, with blackish colour, laminal cells sinuose with dark red-orange walls. This species is rather similar to Schistidium holmenianum in overall appearance and both species grow on soil in tundras. Other species of the genus prefer rocky substrates. Unlike S. holmenianum, S. andreaeopsis has larger and more sinuose distal laminal cells, darker red-orange cell walls, a much weaker costa, and predominantly unistratose and denticulate or papillose-denticulate leaf margins (Ignatova and Blom 2017).

28. Schistidium subflaccidum (Kindb.) H.H.Blom

Contributors. T. Kiebacher and H. H. Blom

Italy. South Tyrol: (1) St Ulrich, Seceda, near Cuca Sattel, $46.58833^{\circ} \mathrm{N}, 11.72150^{\circ} \mathrm{E}$, ca. $2135 \mathrm{~m}$ a.s.l., S-facing rocks, on Breccia (calciferous matrix), 16 August 2017, leg. T. Kiebacher 1464 (priv. herb. T. Kiebacher), conf. H. Blom; (2) Stern, between Forcela de Gherdenacia and Gherdenacia-Hütte, ca. $2100 \mathrm{~m}$ a.s.l., rock boulder in pasture, on dolomite, 19 October 2017, leg. T. Kiebacher 1636 (priv. herb. T. Kiebacher), conf.
H. Köckinger; (3) Trentino, Vigo di Fassa, Mt. Latemar, $46.38328^{\circ} \mathrm{N}, 11.59128^{\circ} \mathrm{E}, 2685 \mathrm{~m}$ a.s.l., S-facing rocks, on basalt, 4 October 2018, leg. T. Kiebacher 1930 (priv. herb. T. Kiebacher); (4) Monte Vigina [?], $1900 \mathrm{~m}$ a.s.l., limestone, leg. Dott. Venturi di Trento, det H.H. Blom (PI).

Schistidium subflaccidum was described as Grimmia subflaccida Kindb. from Canada by Kindberg (1900). Blom et al. (2006) reported the taxon from the Caucasus and provided the first comprehensive description and illustrations. Subsequently the species was reported from a number of European countries including Austria, Albania, France and Switzerland (Köckinger, Suanjak et al. 2008; Ignatova et al. 2009; Chavoutier and Hugonnot 2013; Hodgetts 2015; Swissbryophytes 2019).

In the European Alps the species has been found to be widespread on base-rich siliceous and calcareous rock types (pers. obs.; see Köckinger et al. 2008; Chavoutier and Hugonnot 2013; Schröck et al. 2013; Swissbryophytes 2019).

Here, S. subflaccidum is added to the bryoflora of the Italian Alps, where it seems to be widespread, at least in the region of Trentino-Alto Adige. Schistidium subflaccidum is reported from Italy in the new European checklist of bryophytes (Hodgetts et al. in prep.) based on a pers. comm. of H. Blom in December 2018. This indication is herewith complemented with actual specimens.

29. Seligeria brevifolia (Lindb.) Lindb. \& Arnell Contributor. M. Philippe

France. Auvergne - Rhône - Alpes, Haute-Savoie department, Les Houches, north slope of the Mont Lachat, $45^{\circ} 52^{\prime} 42.16^{\prime \prime} \mathrm{N}, 6^{\circ} 47^{\prime} 21.79^{\prime \prime} \mathrm{E}, 1535 \mathrm{~m}$ a.s.l., Liassic shales of a forest track embankment, in a mixed forest (Abies Mill., Fagus L., Picea A.Dietr.), 18 July 2019, leg. M. Philippe s.n. (LY0027812).

Switzerland. Canton de Vaud, Les Plans sur Bex, Vallon du Nant, 46 $14^{\prime} 42.54^{\prime \prime} \mathrm{N}, 7^{\circ} 06^{\prime} 18.04^{\prime \prime} \mathrm{E}, 1305 \mathrm{~m}$ a.s.l., large bloc of siliceous limestone in a spruce (Picea abies (L.) H.Karst.) forest, and Les Plans sur Bex, below La Thomasia, $46^{\circ} 15^{\prime} 12.78^{\prime \prime} \mathrm{N}, 7^{\circ} 06^{\prime} 36.06^{\prime \prime} \mathrm{E}, 1205 \mathrm{~m}$ a.s.l., limestone bloc in a mixed forest (Fagus, Picea), 23 July 2019, leg. M. Philippe s.n. (LY0027813 and LY0027814 respectively).

This Euro-Siberian species is of least conservation concern at the European scale (Hallingbäck 2019), but in Switzerland it is currently listed as critically endangered (Schnyder et al. 2004). For the European mainland, Scandinavia excepted, it is documented only from the Alps, in Austria, Germany, Switzerland and France (ECCB 1995). Only three of the fifteen total observations from the Alps are dated after 1980, with a single observation each from Austria (Grims 1999), Switzerland (Kiebacher et al. 2019) and Germany (Meinunger and Schröder 2007). 
There have been no records of this species from France since 1977 (Chavoutier 2016). Old records from the French Pyrenees (Husnot 1884-1890) are probably based on a nomenclatural confusion, as Husnot distributed material (Muscologia Gallica $\mathrm{n}^{\circ}$ 754) as Seligeria pusilla var. brevifolia Lindb. that he had received from Culmann, which was collected in the vicinity of Zurich in November 1884. This material was later revealed to be unrelated to Seligeria brevifolia (Lindb.) Lindb. (Culmann 1908). Our new data from France is from the locality described by Culmann (1930). Although works for a forest track have modified the site, probably some decades ago, the species could still be found there. Our data from the Canton de Vaud (two neighbouring sites) are the first reports for this species from this canton of Switzerland.

\section{Sphagnum medium Limpr.}

Contributors. A. V. Shkurko, A. I. Maksimov, O. V. Galanina and E. O. Korolkova

Russia. Pskov Province, Polistovsky State Nature Reserve, Polistovo-Lovatsky ombrotrophic mire massif: (1) $57^{\circ} 03^{\prime} 29.9^{\prime \prime} \mathrm{N}, 30^{\circ} 26^{\prime} 47.3^{\prime \prime} \mathrm{E}$, ca. $96 \mathrm{~m}$ a.s.l., ombrotrophic bog, in wet hollow with Scheuchzeria palustris F.Muell., Rhynchospora alba (L.) Vahl, Drosera rotundifolia L., Sphagnum majus (Russow) C.E.O.Jensen, S. cuspidatum Ehrh. ex Hoffm., 27 June 2016, leg. A. Shkurko, E. Korolkova s.n, det. A. Shkurko (MHA); (2) the same area, $57^{\circ} 03^{\prime} 37.2^{\prime \prime} \mathrm{N}, 30^{\circ} 27^{\prime} 14.9^{\prime \prime} \mathrm{E}$, ca. $97 \mathrm{~m}$ a.s.l., ombrotrophic carpet with Andromeda polifolia L., Oxycoccus palustris (Hill) A.Gray, Carex limosa L., Scheuchzeria palustris, Rhynchospora alba, Drosera rotundifolia, Sphagnum fallax (H.Klinggr.) H.Klinggr., 28 June 2016, leg. E. Korolkova, A. Shkurko s.n., det. A. Shkurko (MHA, MW); (3) the same area, $57^{\circ}$ $14^{\prime} 21.7^{\prime \prime} \mathrm{N}, 30^{\circ} 27^{\prime} 37.2^{\prime \prime} \mathrm{E}$, ca. $92 \mathrm{~m}$ a.s.l., on hummock with Pinus sylvestris L., Chamaedaphne calyculata (L.) Moench, Andromeda polifolia, 23 July 2019, leg. G. Freydin s.n., det. A. Maksimov (PTZ); (4) $57^{\circ}$ $08^{\prime} 17.3^{\prime \prime} \mathrm{N}, 30^{\circ} 30^{\prime} 53.7^{\prime \prime} \mathrm{E}$, on hummock, 26 July 2019, leg. O. Galanina s.n., det. A. Maksimov (PTZ); (5) $57^{\circ}$ $08^{\prime} 50.6^{\prime \prime} \mathrm{N}, 30^{\circ} 31^{\prime} 10.6^{\prime \prime} \mathrm{E}$, on flat hummock with Calluna vulgaris (L.) Hull, Eriophorum vaginatum L., Sphagnum fuscum (Schimp.) H.Klinggr., S. rubellum Wilson, 26 July 2019, leg. O. Galanina s.n., det. A. Maksimov (PTZ).

Sphagnum magellanicum Brid. and S. medium were considered as synonyms, both names have been applied to a morphologically and ecologically variable species, widespread in the Northern Hemisphere. Brotherus (1901), Elenkin (1909), and Podpera (1954) provided records of S. medium from Russian territory, which were later assigned to $S$. magellanicum. However, recent studies have demonstrated that several genetic groups and cryptic taxa exist within this species (Kyrkjeeide et al. 2016; Schwarzer and
Joshi 2017; Yousefi et al. 2017), and three species are now formally recognised (Hassel et al. 2018). According to their results, S. magellanicum has a strictly South American distribution, while the two other species occur in Northern Hemisphere. Of these, a widespread circumboreal species was described as Sphagnum divinum Flatberg \& Hassel, while S. medium was proposed for an Amphi-Atlantic moss, described from the Alps, which occurs in the British Isles, Denmark, Estonia, Germany, Ireland, Latvia, Norway, Sweden, Canada and USA (Hassel et al. 2018). Recently this species was found in Turkey (Ellis, Amélio et al. 2019). Recent revision of collections from the European part of Russia, added some localities for S. medium in the Polistovsky State National Reserve, which are the first Russian records of S. medium s.str. The Reserve lies in the south-western part of the Polistovo-lovatsky mire system, regarded as the largest bog system in Europe (Nosova et al. 2019). The five reported localities of S. medium can be assigned to three different microhabitats: wet ombrotrophic hollows, carpets, and drier hummocks, demonstrating the wide ecological amplitude of the species despite its location at the eastern boundary of its European distribution.

\section{Stereophyllum radiculosum (Hook.) Mitt.}

Contributors. A. Martins, N. Hodgetts, F. Monteiro, L. Catarino and M. Sim-Sim

Republic of Guinea-Bissau. Bijagós Archipelago, Bolama Island, Bolama village, $11.3430^{\circ} \mathrm{N}, 15.2904^{\circ} \mathrm{W}$, $25 \mathrm{~m}$ a.s.l., on trunk of Faidherbia albida (Delile) A.Chev., 26 October 2018, leg. F. Monteiro s.n. (LISU).

Stereophyllum radiculosum has been listed for Mexico, West Indies, Central and South America, Asia, Africa and Australia (Buck and Ireland 2014). This species is recognised by its dull, complanate, singly costate leaves with short, rhomboidal laminal cells usually with a single papilla over the lumen (Buck and Ireland 2014).

This collection was made in an open forest from a trunk of Faidherbia albida.

32. Taxiphyllum wissgrillii (Garov.) Wijk \& Margad. Contributors. D. Dagnino, C. Turcato and L. Minuto Italy. Liguria Region, Beigua Regional Natural Park, Mt. Beigua, Prariondo, Bric Sciue Gianche, $1156 \mathrm{~m}$

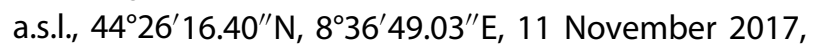
leg. D. Dagnino s.n., det D. Dagnino \& C. Turcato (GE, B148).

This is the first record of Taxiphyllum wissgrillii for the Liguria Region. This species is distributed in Eurasia and northern Africa (Dierßen 2001) and occurs in several Mediterranean countries (Ros et al. 2013). In Italy T. wissgrillii was known from several administrative regions, particularly in the northern part of the Peninsula (Aleffi et al. 2008). 
It usually grows in moist, shady places, on various types of substrate (Dierßen 2001). The site of the discovery is a serpentinite outcrop in a deciduous mesophilic forest dominated by beech (Fagus sylvatica L., referring to the Fagion silvaticae alliance), in the Beigua Regional Natural Park. This area is characterised by a sub-oceanic climate, very close to that of the Mediterranean.

33. Thysananthus auriculatus (Wilson) Sukkharak \& Gradst.

Contributors. A. Martins, N. Hodgetts, F. Monteiro, L. Catarino and M. Sim-Sim

Republic of Guinea-Bissau. Bijagós Archipelago, Marine National Park of João Vieira Poilão, Cavalos Island, $11.011528^{\circ} \mathrm{N}, 15.708694^{\circ} \mathrm{W}$, ca. $20 \mathrm{~m}$ a.s.l., on trunk of Sterculia tragacantha Lindl., 11 July 2016, leg. L. Catarino \& B. Indjai s.n. (LISU).

Thysananthus auriculatus [ $\equiv$ Mastigolejeunea auriculata (Wilson) Steph.] is a widespread species in tropical America and tropical Africa (Sukkharak and Gradstein 2014). This is the first confirmed record of the species for Guinea-Bissau, although Catarino et al. (2006) reported 'Mastigolejeunea aff. auriculata' for the Cantanhez region (Guinea-Bissau).

Thysananthus auriculatus is characterised by its dark green to blackish colour, the strongly convex, and sometimes subsquarrose, leaves with upcurved to incurved ventral margins, the apical margin of the lobule obliquely running into the ventral margin of the leaf lobe and the usually plane lateral margins of the underleaves (Sukkharak and Gradstein 2014).

The new specimen was found on the trunk of Sterculia tragacantha Lindl. in a palm grove.

\section{Tortella alpicola Dixon}

Contributor. T. Kiebacher

Italy. (1) Trentino, Vigo di Fassa, Kleine Latemarscharte, $46.38529^{\circ} \mathrm{N}, 11.59763^{\circ} \mathrm{E}, 2515 \mathrm{~m}$ a.s.l., E-facing rock, on dolomite, 4 October 2018, leg. T. Kiebacher 1929 (priv. herb. T. Kiebacher); (2) Belluno, Cortina d'Ampezzo, NNW ridge to the summit of Mt. Tofana di Rozes, along path to the summit, $46.54004^{\circ} \mathrm{N}, 12.04783^{\circ} \mathrm{E}$, $3032 \mathrm{~m}$ a.s.l., exposed ridge, $\mathrm{N}$-facing rocks, in rock fissure, on dolomite, 19 September 2019, leg. T. Kiebacher 2258 (priv. herb. T. Kiebacher), conf. H. Köckinger; (3) Belluno, Cortina d'Ampezzo, Mt. Tofana di Rozes, summit area, $46.53717^{\circ} \mathrm{N}, 12.05098^{\circ}$ $\mathrm{E}, 3220 \mathrm{~m}$ a.s.l., NE-exposed ridge, exposed rock outcrops, on dolomite, 19 September 2019, leg. T. Kiebacher 2270 (priv. herb. T. Kiebacher).

The occurrence of Tortella alpicola in Europe was recognised some 15 years ago (Otnyukova et al. 2004; Rams et al. 2006) and this late discovery is surely due to the similarity of the taxon to $T$. fragilis (Drumm.) Limpr. Tortella fragilis is widespread and locally abundant in European mountain regions. Both species have long acuminate and easily broken leaf apices that are usually erect when the plants are wet. However, T. alpicola differs from T. fragilis in the barrel-shaped segmentation of the leaf acumen where distinct constrictions predefine breaking points, and conspicuously shiny, white basal leaf cells. By contrast, $T$. fragilis lacks constrictions in the leaf acumen and the hyaline basal cells are yellowish-white.

Tortella alpicola was described from the Himalaya Mountains (Dixon 1930) and was first reported for Europe from the Urals (Otnyukova et al. 2004). Rams et al. (2006) reported the species from the Sierra Nevada and subsequently it was recorded in European mountain areas of France, Norway, Austria, Switzerland and the Canary Islands (Dirkse and Losada-Lima 2011; Chavoutier and Hugonnot 2013; Schröck et al. 2013; Bergamini et al. 2015, 2017; Köckinger et al. 2016; Swissbryophytes 2018). Here, the Italian Alps are added to the known distribution of the taxon. The species was recorded in the central Alps on calcareous schist and in the southern Alps on dolomite. All records are from high elevations, partly exceeding $3000 \mathrm{~m}$ a.s.l.

\section{Tortella fragilis (Drumm.) Limpr.}

\section{Contributor. R. Ochyra}

Antarctica, South Shetland Islands. Livingston Island: South Bay, Hurd Peninsula, Johnsons Dock area, $62^{\circ}$ $39^{\prime} 38^{\prime \prime} \mathrm{S}, 60^{\circ} 22^{\prime} 39^{\prime \prime} \mathrm{W}$, ca. $45 \mathrm{~m}$ a.s.l., in moist but exposed and sunny cracks of calciphilous rocks, 12 February 1992, leg. F. Schulz s.n. (KRAM B-250520).

Tortella fragilis is a fairly rare and localised species in the maritime Antarctic. It is locally common and abundant only on Alexander Island and on James Ross Island and occasional and widely scattered along the western and eastern coasts of the Antarctic Peninsula (Ochyra, Bednarek-Ochyra et al. 2008; Ochyra, Lewis Smith et al. 2008). In the peri-Antarctic archipelagoes it was only once recorded on King George Island, the largest of the South Shetland Islands (Wierzgoń et al. 2018) and herein it is recorded from Livingston Island, the second largest island of this archipelago. It was formerly recorded from this island as $T$. fragilis var. tortelloides (S.W.Greene) R.H.Zander \& Hoe (Sancho et al. 1999). This is a notable addition to the moss flora of this island which currently consists of 57 species, eight of which belong to the Pottiaceae, including three of Syntrichia Brid., two of Hennediella Paris and three each of Tortella (Müll.Hal.) Limpr., Didymodon Hedw. and Bryoerythrophyllum P.C.Chen (Ochyra and Zander 2002; Ochyra, Lewis Smith et al. 2008). Tortella fragilis is very rare in the austral polar regions and outside the Antarctic it is known only from subantarctic South Georgia (Ochyra, Bednarek-Ochyra et al. 2002) and Îles Kerguelen (Ochyra and Poulsen 2003). 
36. Tortella mediterranea Köckinger, Lüth, O.Werner \& Ros

Contributors. P. Erzberger and H. Köckinger

Montenegro. (1) Rumija Mts, at Skadarsko jezero (Lake Scutari), district of Ulcinj, at the border of Albania north-west to Shtegvasha village, limestone outcrops in open vegetation, $475 \mathrm{~m}$ a.s.l., $42^{\circ} 03^{\prime} 52.2^{\prime \prime} \mathrm{N}$, $19^{\circ}$ $22^{\prime} 31.2^{\prime \prime} \mathrm{E}$, 8 October 2003, leg. P. Erzberger \& B. Papp s.n. (B-Erzberger 9715, 9718, priv. herb. Köckinger), [as Tortella tortuosa (Hedw.) Limpr., rev. H. Köckinger]. (2) Orjen Mts, district of Herceg Novi, between the villages Vrbanje and Kruševice, limestone rocks partly shaded by broad-leaved trees, $1010 \mathrm{~m}$ a.s.l., $42^{\circ} 32^{\prime} 58.0^{\prime \prime} \mathrm{N}, 18^{\circ}$ $30^{\prime} 19.4^{\prime \prime} \mathrm{E}, 16$ July 2007, leg. P. Erzberger \& B. Papp s.n. (B-Erzberger 12330, 12338, priv. herb. Köckinger), [as Tortella tortuosa rev. $\mathrm{H}$. Köckinger].

A revision of collections of Tortella from the western Balkan Peninsula revealed the fourth and fifth record of the recently described $T$. mediterranea (Köckinger et al. 2018). These records from southern Montenegro form a bridge between two of the three hitherto known localities from Croatia and Greece. Four of the known occurrences are situated in the prominent mesozoic limestone mountain range east of the Adriatic that extends from Istria to northern Greece, which appears to be the main distribution area.

Habitat conditions of the newly found populations correspond to the previous finds, which were all from limestone. However, the second collection was from a distinctly higher elevation (1010 $\mathrm{m}$ a. s. I.) than previously recorded (200, 500 and $620 \mathrm{~m}$ a.s.l. respectively), and the associated bryophytes, Plagiopus oederianus (Sw.) H.A.Crum \& L.E.Anderson, Ctenidium molluscum (Hedw.) Mitt., Orthothecium rufescens (Dicks. ex Brid.) Schimp. and Gymnostomum aeruginosum Sm., have to be regarded as more cryophilous than expected. Nevertheless, both localities are situated very close to the Adriatic. South-western Montenegro and in particular the Orjen Mountains receive Europe's heaviest precipitation (more than $6000 \mathrm{~mm}$ ). Seemingly, T. mediterranea, prefers mountaineous limestone areas with heavy winter rain close to the sea, which is also true for the type locality on Mallorca.

Tortella mediterranea can be recognised by the following combination of characters: (1) absence of a stem central strand, (2) narrowly lanceolate leaves with an ovate base and a narrow mucro, (3) partial presence of elongate marginal cells in upper leaf, (4) small laminal cells, (5) rather gradual limb-sheath transition and (6) the ventral costal stereid band usually thicker than the dorsal.

37. Warnstorfia sarmentosa (Wahlenb.) Hedenäs Contributors. I. Parnikoza, V. Ivanets, M. Wierzgoń and R. Ochyra

Antarctic Peninsula, Graham Coast. West Antarctic Peninsula, Kiev Peninsula, Oasis Rasmussen, western slope, $65^{\circ} 14^{\prime} 52.116^{\prime \prime} \mathrm{S}, 64^{\circ} 04^{\prime} 59.52^{\prime \prime} \mathrm{W}, 25 \mathrm{~m}$ a.s.l., in wet place in moss carpet formation, associated with Sanionia georgicouncinata (Müll.Hal.) Ochyra \& Hedenäs, Warnstorfia fontinaliopsis (Müll.Hal.) Ochyra, Pohlia nutans (Hedw.) Lindb. and Brachythecium austrosalebrosum (Müll.Hal.) Kindb., 7 March 2019, leg. et det. I. Parnikoza s.n., ver. R. Ochyra (KRAM B-248847). Antarctica, Wilhelm Archipelago. Lemaire Channel, northern face of Booth Island, $65^{\circ} 02^{\prime} 40.956^{\prime \prime} \mathrm{S}, 63^{\circ}$ $56^{\prime} 08.736^{\prime \prime} \mathrm{W}, 28 \mathrm{~m}$ a.s.l., moss in the rock cervices, associated with Sanionia uncinata (Hedw.) Loeske and Andreaea regularis Müll.Hal., 1 April 2019, leg. et det. I. Parnikoza s.n., ver. R. Ochyra (KRAM B-248841).

Warnstorfia sarmentosa is a common species in the South Orkney Islands and the South Shetland Islands in the northern maritime Antarctic. Additionally, it has been recorded from James Ross Island off the East Antarctic Peninsula and on Cape Kjelmann on Davis Coast on the West Antarctic Peninsula. Its southernmost locality was found at lat. $65^{\circ} 32^{\prime} \mathrm{S}$ on Lahille Island in the Grandidier Channel off Graham Coast (Ochyra, Lewis Smith et al. 2008). Herein, W. sarmentosa is collected for the second time from the mainland Antarctic Peninsula from Rasmussen Oasis on Graham Coast and from Booth Island in Wilhelm Archipelago. At both sites it is a component of the moss carpet subformation which is widespread in this area (Parnikoza et al. 2018). In Wilhelm Archipelago only the moss flora of the Argentine Islands was surveyed by Lewis Smith and Corner (1973), whose moss collection consisted of 32 species (Ochyra, Lewis Smith et al. 2008). Recent field studies yielded four additional species (Blockeel et al. 2006; Ellis, Alataş et al. 2016; Ellis, Aleffi, Alegro et al. 2016; Ellis, Asthana, Srivastava, Omar, et al. 2016), increasing the moss flora of the Argentine Islands to 36 species. Generally, in the region between Lemaire Channel and Lahille Island in the north-south gradient and Cruls and Roca Islands - Graham Coast in the west-east direction some 49 moss species have been recorded (Ochyra, Lewis Smith et al. 2008). The species richness of this insular area is remarkable and justifies its recognition as an Antarctic Specially Protected Area.

\section{Acknowledgements}

L. T. Ellis acknowledges the support of the Natural History Museum, London, UK. T. Kiebacher thanks H. Köckinger for the confirmation of determination of a specimen of Schistidium subflaccidum and for the critical examination of Tortella alpicola specimens, and thanks G. Buzas for linguistic correction. Dr M. Philippe thanks Ariel Bergamini, Vincent Hugonnot, Marta Infante Sánchez and Markus Meier who kindly helped to prepare his note. The research of R. A. Cabral, S. Jimenez and G. M. Suárez was sponsored by the Consejo Nacional de Investigaciones Científicas y Técnicas (CONICET), SGCyT (PI 16P002), the Program PICT (0810) and PIUNT (G631) from Argentina. These authors gratefully acknowledge Dr Juçara Bordin for confirming the identification of species. 
A. D. Potemkin is grateful to Nele Ingerpuu for information on habitat and distribution of Lophozia perssonii in Estonia. The study of A. D. Potemkin was carried out in the framework of the institutional research project of Komarov Botanical Institute of the Russian Academy of Sciences "Flora and systematics of lichens and bryophytes of Russia and phytogeographically important regions" (AAAA-A19-119020690077-4). The field work of R. Medina was funded by the United States National Science Foundation (DEB-1753673). He also acknowledges A. Manteca for his assistance in the field. A. V. Shkurko is grateful to V. E. Fedosov for support and encouragement. The work of A. V. Shkurko was supported by governmental contract 118021490111-5 of Tsitsin' Main Botanical Garden of RAS. The work of A. I. Maksimov was carried out within the framework of the institutional research project 0218-2019-0078 and the research agreement between O. V. Galanina and the Polistovsky State Nature Reserve. P. Saha, Md. N. Aziz and D. Maity are grateful to the present Director (Dr A. A. Mao) and ex-Director (Dr P. Singh) of the Botanical Survey of India for encouragement and facilities.

The contributions by R. Ochyra have been financially supported by the statutory fund of the W. Szafer Institute of Botany of the Polish Academy of Sciences. He also thanks the curators at BM, H, JE and PC for the loan of specimens. The notes of V. Plášek are part of research projects of EU structural funding Operational Programme Research and Development for Innovation, project No. CZ.1.05/2.1.00/19.0388 and by the Ministry of Education, Youth and Sports of the Czech Republic in the "National Feasibility Program I", project LO1208 "TEWEP". The contribution by I. Parnikoza and V. Ivanets had the financial support of the National Antarctic Research Centre of the Ministry of Education and Science of the Ukraine. Their research was performed as part of the national targeted scientific and technological programme of research in the Antarctic for 2011-2020. Mariusz Wierzgoń was funded by the statutory funds of the Institute of Biology, Biotechnology and Environmental Protection of the University of Silesia in Katowice.

The field work of M. S. Ignatov and E. A. Ignatova was supported by RFBR 19-04-00976. The study by O. M Afonina was carried out within the framework of the institutional research project «Herbarium collections of BIN RAS (history, conservation, investigation and replenishment)» AAA-A18-1180222090078-2. The contribution of S. G. Kazanovsky was supported by Grant № 18-04-00822 of the Russian Fund for Basic Research (RFBR) «Bryocomponent of vegetation in the south of Siberia». S. Ştefănuț acknowledges the support by project no. RO1567IBB03/2019 through Institute of Biology Bucharest of Romanian Academy. The work of I. V. Czernyadjeva and L. A. Konoreva was supported by Russian Foundation for Basic Research (grants \# 18-05-60093) and it was carried out within the framework of the institutional research project (no. AAAA-A19119020690077-4) of the Komarov Botanical Institute of the Russian Academy of Sciences. A. Uygur, T. Ezer, S. Karaman Erkul and M. Alataş gratefully acknowledge the financial support of the Turkish Scientific and Technical Research Council (TUBITAK, Project Number: 120Z046).

\section{ORCID}

R. Medina (D) http://orcid.org/0000-0001-5629-1503

R. Ochyra (D) http://orcid.org/0000-0002-2541-0722

\section{References}

Afonina OM. 2015. Mosses. In: Matveyeva NV, editor. Plants and fungi of the polar deserts in the northern hemisphere. St Petersburg: Komarov Botanical Institute; p. 75-116. Russian.
Afonina OM, Raynolds MK, Walker DA. 2005. On the moss flora of Mould Bay (Prince Patrick Island, Canadian Arctic Archipelago). Arctoa. 14:135-142.

Aleffi M, Tacchi R, Cortini Pedrotti C. 2008. Check-list of the hornworts, liverworts and mosses of Italy. Bocconea. 22:5-254.

Anderson L. 1954. Hoyer's solution as a rapid permanent mounting medium for bryophytes. The Bryologist. 57:242-244.

Bakalin VA, Cherdantseva V. 2006. Bryophytes of northern Kuril Islands (north-west Pacific). Arctoa. 15:131-153.

Bednarek-Ochyra H, Ochyra R. 2011. Bucklandiella angustissima sp. nov. (Grimmiaceae), a new austral amphipacific species with the smallest capsules and the shortest setae in the genus. Cryptogamie, Bryologie. 32:13-27.

Bednarek-Ochyra H, Ochyra R. 2012a. The taxonomic status of Racomitrium capense (Bryophyta, Grimmiaceae) from South Africa. Cryptogamie. Bryologie. 33:97-106.

Bednarek-Ochyra H, Ochyra R. 2012b. A consideration of Bucklandiella (Bryophyta, Grimmiaceae) in South America, with a taxonomic re-assessment of Racomitrium looseri. Nova Hedwigia. 95:153-163.

Bednarek-Ochyra H, Ochyra R. 2013. Diversity of Grimmiaceae subfam. Racomitrioideae in sub-Saharan Africa, including an addition of Bucklandiella striatipila to the moss flora of the continent. Cryptogamie, Bryologie. 34:3-12.

Bednarek-Ochyra H, Ochyra R, Buck WR. 1999. The genus Racomitrium (Grimmiaceae) in Brazil, with the first report of $R$. subsecundum in South America. Brittonia. 51:93-105.

Bednarek-Ochyra H, Ochyra R, Sawicki J, Szczecińska M. 2014. Bucklandiella seppeltii, a new species of Grimmiaceae from Australasia and its phylogenetic position based on molecular data. Turkish Journal of Botany. 38:1214-1228.

Bednarek-Ochyra H, Sawicki J, Ochyra R, Szczecińska M, Plášek V. 2015. Dilutineuron, a new moss genus of the subfamily Racomitrioideae (Grimmiaceae, Bryophyta). Acta Musei Silesiae, Scientiae Naturales. 64:163-168.

Bergamini A, Hofmann H, Kiebacher T, Müller N, Peintinger M, Schnyder N. 2017. Beiträge zur bryofloristischen Erforschung der Schweiz - Folge 12. Meylania. 59:13-28.

Bergamini A, Schnyder N, Lüth M, Hofmann H, Holderegger R, Kiebacher T, Müller N. 2015. Beiträge zur bryofloristischen Erforschung der Schweiz - Folge 10. Meylania. 15:16-29.

Blockeel TL, Bednarek-Ochyra H, Ochyra R, Cykowska B, Esquivel MG, Lebouvier $M$, Luis $L$, Martins $S$, Müller $F$, Németh CS, et al. 2009. New national and regional bryophyte records, 21. Journal of Bryology. 31:132-139.

Blockeel TL, Bednarek-Ochyra H, Ochyra R, Hájková P, Hájek $M$, Kučera J, Kürschner $H$, Müller $F$, Oliván $G$, Parolly $G$, et al. 2006. New national and regional bryophyte records, 13. Journal of Bryology. 28:151-155.

Blom HH, Ignatova EA, Afonina OM. 2006. New records of Schistidium (Grimmiaceae, Musci) in Russia. Arctoa. 15:187-194.

Boiko MF. 1992. Bryoflora stepnoi zony VostochnoEvropeiskoi ravniny i Predkavkasia. Diss ... dokt. biol. nauk .- K. Russian.

Boiko MF. 2008. Cheklist mochopodibnykh Ukrayiny. Kherson: Aylant. Ukrainian.

Boiko MF. 2009. Bryobionta of the steppe of Ukraine: Monografy. Kherson: Ailant. Ukrainian.

Bordin J, Yano O. 2013. Fissidentaceae (Bryophyta) do Brasil. Boletim do Instituto de Botânica. 22:1-168.

Brotherus VF. 1901. Bryales. In: Engler A, Prantl K, editors. Die Natürlichen Pflanzenfamilien, ed. 1, vol. 1(3). Leipzig: Engelmann; p. 289-336.

Brullo S, Privitera M, Puglisi M. 2001. Phytogeographical considerations on the fumarole bryoflora from Mediterranean and Macaronesian areas. Bocconea. 13:329-336. 
Buck WR, Ireland RR. 2014. Stereophyllaceae. In: Flora of North America Editorial Committee, editors. Flora of North America north of Mexico. Vol. 28. Bryophyta, part 2. New York (NY): Oxford University Press; p. 469471.

Cajade R, Medina W, Salas R, Fandiño B, Paracampo A, García I, Pautasso A, Piñeiro JM, Acosta JL, Zaracho VH, et al. 2013. Las islas rocosas del Paraje Tres Cerros: un refugio de biodiversidad en el litoral mesopotámico argentino. Biológica. 16:147-159.

Camus F. 1902. Note préliminaire sur un voyage bryologique en Corse. Revue Bryologique. 29(2):17-26.

Carnevali R. 1994. Fitogeografía de la provincia de Corrientes: cartas, escalas 1: 500.000 y 1: 1.000. 000. Gobierno de la Provincia de Corrientes.

Catarino L, Martins E, Pinto-Basto MF, Diniz MA. 2006. Plantas vasculares e briófitos da Guiné-Bissau. Lisboa: IICT/IPAD.

Chavoutier L. 2016. Troisième mise à jour de la publication mousses, hépatiques et anthocérotes du département de la Savoie. Bulletin Mycologique et Botanique DauphinéSavoie. 222:25-62.

Chavoutier L, Hugonnot V. 2013. Mousses, hépatiques et anthocérotes du département de la Savoie (France). Sevrier: Fédération Mycologique et Botanique DauphinéSavoie.

Cherdantseva V. 2006. Mosses (Bryopsida) of the Moneron Island. In: Rastitelnyi i zhivotnyi mir ostrova Moneron (Materialy mezhdunarodnogo Sakhalinskogo proekta. Vladivostok); p. 48-54. Russian.

Cherdantseva V, Gorobets KV, Harpel J, Ignatov MS, Ignatova EA, Teleganova VV. 2006. New moss records from Sakhalinskaya Province 1. Sakhalin. Arctoa. 15:263-267.

Číhal L, Kaláb O, Plášek V. 2017. Modeling the distribution of rare and interesting moss species of the family Orthotrichaceae (Bryophyta) in Tajikistan and Kyrgyzstan. Acta Societatis Botanicorum Poloniae. 86:35-43.

Clifford HT. 1955. On the distribution of Rhacomitrium crispulum. The Bryologist. 58:330-334.

Crosby MR, Magill RE, Allen B, He S. 1999. A check list of the mosses. St. Louis (MO): Missouri Botanical Garden.

Crosby MR, Schultze-Motel U, Schultze-Motel W. 1983. Katalog der Laubmoose von Madagaskar und den umliegenden Inseln. Willdenowia. 13:187-255.

Culmann P. 1908. Le vrai Seligeria brevifolia Lindb. trouvé en Suisse. Revue Bryologique. 35(3):79-80.

Culmann P. 1930. Contribution à la flore bryologique du basin supérieur de l'Arve. Bulletin de la Société Botanique de France. 77:463-473.

Czernyadjeva IV. 1995. Philonotis yezoana Besch. et Card. ex Card. (Bartramiaceae, Musci). Arctoa. 4:15-16.

da Silva MSD, Peralta DF. 2017. Pseudephemerum nitidum (Hedw.) Loeske (Bryophyta) rediscovered in Brazil. Check List. 13:739-742.

De Sloover JL. 1976. Note de bryologie africaine VII. Pseudephemerum, Bryohumbertia, Eucladium, Streptopogon, Ptychomitrium, Rhachithecium, Antitrichia, Pterogonium, Lindigia, Distichophyllum. Bulletin du Jardin Botanique National de Belgique/Bulletin van de National Plantentuin van België. 46:427-447.

De Sloover JL. 1977. Note de bryologie africaine IX. Andreaea, Racomitrium, Gymnostomiella, Thuidium. Bulletin du Jardin Botanique National de Belgique. 47:155-181.

Dierßen K. 2001. Distribution, ecological amplitude and phytosociological characterization of European bryophytes. Bryophytorum Bibliotheca. 56:1-289.
Dirkse GM, Losada-Lima A. 2011. Additions and amendments to the moss flora of the Canary Islands. Cryptogamie, Bryologie. 32:37-41.

Dixon HN. 1930. Additions to the moss flora of the northwestern Himalayas. Annales Bryologici. 111:51-77.

Eckel PM. 2007. Hyophila. In: Flora of North America Editorial Committee, editors. Flora of North America north of Mexico. Vol. 27. Bryophyta, Mosses, part 1. New York (NY): Oxford University Press; p. 584-585.

Elenkin AA. 1909. Moss flora of Central Russia, part 1. Publ. Sheremet'ev Nat. Hist. Mus. in Michajlowskoje, Dept. of Moscow. 6:1-9.

Ellis LT. 2018. Taxonomic notes on Calymperes erosum Müll.Hal. (Calymperaceae), C. palisotii Schwägr. and related West African taxa. Journal of Bryology. 40:333-341.

Ellis LT, Akhoondi Darzikolaei S, Shirzadian S, Bakalin VA, Bednarek-Ochyra H, Ochyra R, Claro D, Dulin MV, Eckel PM, Erzberger $P$, et al. 2011. New national and regional bryophyte records, 29. Journal of Bryology. 33:316-323.

Ellis LT, Alataş M, Asthana AK, Rawat KK, Sahu V, Srivastava A, Bakalin VA, Batan N, Bednarek-Ochyra H, Bester SP, et al. 2016. New national and regional bryophyte records, 47. Journal of Bryology. 38:151-167.

Ellis LT, Aleffi M, Alegro A, Segota V, Asthana AK, Gupta R, Singh VJ, Bakalin VA, Bednarek-Ochyra H, CykowskaMarzencka B, et al. 2016. New national and regional bryophyte records, 48. Journal of Bryology. 38:235-259.

Ellis LT, Aleffi M, Asthana G, Bhagat C, Bakalin VA, Baráth K, Becker R, Bednarek-Ochyra H, Boiko M, et al. 2018. New national and regional bryophyte records, 57. Journal of Bryology. 40:399-419.

Ellis LT, Aleffi $M$, Tacchi R, Alegro A, Alonso M, Asthana AK, Sahu V, Biasuso AB, Callaghan DA, Ezer T, et al. 2014. New national and regional bryophyte records, 41 . Journal of Bryology. 36:306-324.

Ellis LT, Alegro A, Bansal P, Nath V, Cykowska B, BednarekOchyra H, Ochyra R, Dulin MV, Erzberger P, Garcia C, et al. 2012. New national and regional bryophyte records, 32. Journal of Bryology. 34:231-246.

Ellis LT, Amélio LA, Peralta DF, Bačkor M, Baisheva EZ, Bednarek-Ochyra $H$, Burghardt $M$, Czernyadjeva IV, Kholod SS, Potemkin AD, et al. 2019. New national and regional bryophyte records, 59. Journal of Bryology. 41:177-194.

Ellis LT, Asthana AK, Srivastava A, Bakalin VA, BednarekOchyra H, Cano MJ, Jiménez JA, Alonso M, Deme J, Csiky $J$, et al. 2015. New national and regional bryophyte records, 43. Journal of Bryology. 37:128-147.

Ellis LT, Asthana AK, Srivastava P, Omar I, Rawat KK, Sahu V, Cano MJ, Costa DP, Dias EM, Dias dos Santos N, et al. 2016. New national and regional bryophyte records, 46. Journal of Bryology. 38:47-63.

Ellis LT, Bakalin VA, Baisheva E, Bednarek-Ochyra H, Ochyra R, Borovichev EA, Choi SS, Sun B-Y, Erzberger P, Fedosov VE, et al. 2013. New national and regional bryophyte records, 36. Journal of Bryology. 35:228-238.

Ellis LT, Bayliss J, Bruggeman-Nannenga MA, Cykowska B, Ochyra R, Gremmen NJM, Frahm J-P, Hedderson TA, Heras $P$, Infante VM, et al. 2014. New national and regional bryophyte records, 38. Journal of Bryology. 36:61-72.

Erdağ A, Kürschner H. 2017. Türkiye Bitkileri Listesi (Karayosunları). İstanbul: Ali Nihat Gökyiğit Vakfı Yayını. Turkish.

European Committee for Conservation of Bryophytes (E.C.C.B.). 1995. Red data book of European Bryophytes. Trondheim: ECCB. 
Ezer T. 2016. Fissidens gymnandrus (Bryophyta, Fissidentaceae), a new moss record from Turkey and southwest Asia. Phytologia Balcanica. 22:3-5.

Frey W, Frahm J-P, Fischer E, Lobin W. 2006. The liverworts, mosses and ferns of Europe. English Edition TL Blockeel. Colchester: Harley Books.

Frisvoll AA. 1988. A taxonomic revision of the Racomitrium heterostichum group (Bryophyta, Grimmiaceae) in N. and C. America, Europe and Asia. Gunneria. 59:1-289.

Gangulee HC. 1971. Mosses of eastern India and adjacent regions. Fascicle 2. Archidiales, Dicranales \& Fissidentales. Calcutta: H.C. Gangulee; p. 171-566.

Gangulee HC. 1980. Mosses of eastern India and adjacent regions. Fascicle 8. Hypnobryales-Hypineae. Calcutta: H.C. Gangulee; p. 1753-2145.

Gradstein SR, Churchill S, Salazar-Allen N. 2001. Guide to the bryophytes of tropical America. Memoirs of the New York Botanical Garden. 86:1-577.

Gorobets KV, Smirnova IL. 2004. A new location of Philonotis yezoana Besch. et Card. (Bartramiaceae, Musci) in Russia. In: VII Regional'naya konferentsiya po aktual'nym problemam ekologii, morskoy biologii i biotekhnologii studentov, aspirantov, molodykh prepodavateley i sotrudnikov vuzov i nauchnykh organizatsyi Dal'negoVostoka Rossii:34. Russian.

Greven H. 1997. Grimmia austro-funalis C. Müll.,a species with a misleading name and a disjunct distribution. Journal of Bryology. 19:827-830.

Grims F. 1999. Die Laubmoose Österreichs (Catalogus Florae Austriae, II. Teil, Bryophyten (Moose), Heft 1, Musci (Laubmoose)). In: Ehrendorfer F, editor. Biosystematics and Ecology Series, Band: 15. Wien: VÖAW.

Guerra J, Heras P, Infante M. 2012. Fissidens bryoides var. gymnandrus and $F$. celticus (Bryophyta, Fissidentaceae) in the Iberian Peninsula. Cryptogamie, Bryologie. 33:149-154.

Hallingbäck T. 2019. Seligeria brevifolia. The IUCN Red List of Threatened Species 2019: e.T85849850A87840881 [accessed 2019 Nov 12].

Hassel K, Kyrkjeeide MO, Yousefi N, Prestø T, Stenøien HK, Shaw JA, Flatberg KI. 2018. Sphagnum divinum (sp. nov.) and S. medium Limpr. and their relationship to S. magellanicum Brid. Journal of Bryology. 40:197-222.

Hedwig J. 1801. Species Muscorum Frondosorum descriptae et tabulis aeneis LXXVII coloratis illustratae. Opus posthumum editum a Frederico Schwägrichen. Leipzig: J. Barth.

Hodgetts N. 2019. Fissidens celticus. The IUCN Red List of Threatened Species 2019: e.T84768113A87794551. [accessed 2019 Nov 20]. http://dx.doi.org/10.2305/IUCN. UK.2019-2.RLTS.T84768113A87794551.en.

Hodgetts NG. 2015. Checklist and country status of European bryophytes - towards a new Red List for Europe. Irish Wildlife Manuals, No. 84. National Parks and Wildlife Service, Department of the Arts, Heritage and the Gaeltacht, Ireland.

Husnot T. 1884-1890. Muscologia gallica. Descriptions \& figures des mousses de France et des contrées voisines. Première partie. Acrocarpes. Cahan: private edition.

Ignatov MS, Afonina OM, Ignatova EA. 2006. Check-list of mosses of east Europe and North Asia. Arctoa. 15:1-130.

Ignatova EA, Blom HH. 2017. Schistidium. In: Ignatov MS, editor. Moss flora of Russia. Vol. 2: Oedipodiales Grimmiales. Moscow: KMK Scientific Press Ltd; p. 438551. Russian and English.

Ignatova EA, Blom HH, Goryunov DV, Milyutina IA. 2009. On the genus Schistidium (Grimmiaceae, Musci) in Russia. Arctoa. 19:195-233.
Ingerpuu N, Vellak K, Ehrlich L. 2018. Revised Red Data List of Estonian bryophytes. Folia Cryptogamica Estonica. 55:97-104.

Ireland RR, Bellolio G, Larraín J, Rodríguez R. 2017. Studies on the moss flora of the Bío-Bío Region of Chile: part 3. PhytoKeys. 77:1-20.

Iwatsuki Z. 1980. Notes on genera Pseudephemerum (Lindb.) Hag. and Nanomitriopsis Card. Miscellanea Bryologica et Lichenologica. 8:129-133.

Kiebacher T, Meier M, Büschlen A, Schnyder N. 2019. Additions to the bryoflora of Switzerland. Herzogia. 32:136-153.

Kimmerer RW. 1991. Reproductive ecology of Tetraphis pellucida II. Differential success of sexual and asexual propagules. The Bryologist. 94:284-288.

Kindberg NC. 1900. Additions to the North American and European bryology (moss-flora). Ottawa Naturalist. 14:7788.

Köckinger H, Lüth M, Werner O, Ros RM. 2018. Tortella mediterranea (Pottiaceae), a new species from Southern Europe, its molecular affinities, and taxonomic notes on T. nitida. The Bryologist. 121:560-570.

Köckinger H, Schröck C, Zechmeister H. 2016. Checkliste der Moose Österreichs. Version 27.11.2019. Vienna: University of Vienna; [accessed 2020 Jan 1]. http://cvl.univie.ac.at/ projekte/moose/.

Köckinger H, Suanjak M, Schriebl A, Schröck C. 2008. Die Moose Kärntens. Klagenfurt: Verlag des Naturwissenschaftlichen Vereins für Kärnten. German.

Koponen T, Ignatova EA. 2018. Genus Philonotis Brid. In: Moss flora of Russia. Vol. 4. Bartramiales - Aulacomniales. Ignatov MS, editor-in-Chief. Moscow: KMK Scientific Press Ltd; p. 23-45. Russian and English.

Koponen T, Ignatova EA, Kuznetsova Ol, Ignatov MS. 2012. The genus Philonotis (Bartramiaceae, Musci) in Russia. Arctoa. 21:21-62.

Kyrkjeeide MO, Hassel K, Flatberg Kl, Shaw AJ, Yousefi N, Stenøien HK. 2016. Spatial genetic structure of the abundant and widespread peatmoss Sphagnum magellanicum Brid. PLoS One. 11(2):e0148447.

Lal J. 2005. A checklist of Indian mosses. Dehra Dun: Bishen Singh Mahendra Pal Singh.

Larraín J. 2016. The mosses (Bryophyta) of Capitán Prat Province, Aisén Region, southern Chile. PhytoKeys. 68:91116.

Larraín J, Bahamonde N. 2017. Los briófitos de la Estancia Cerro Paine, Parque Nacional Torres del Paine, Magallanes, Chile. Boletín de la Sociedad Argentina de Botánica. 52:27-38. Spanish.

Lawton E. 1973. Rhacomitrium crispulum and some related species. Bulletin of the Torrey Botanical Club. 100:230-235.

Lewinsky-Haapasaari J. 1996. Orthotrichum holmenii, a new corticolous species from Kazakhstan with comments on Orthotrichum hallii in Asia. The Bryologist. 99:1-5.

Lewis Smith Rl, Corner RWM. 1973. Vegetation of the Arthur Harbour-Argentine Islands region of the Antarctic Peninsula. British Antarctic Survey Bulletin. 33/34:89-122.

Maier E. 2010. The genus Grimmia Hedw. (Grimmiaceae, Bryophyta). A morphological-anatomical study. Boissiera. 63:1-377.

Mamatkulov UK, Baitulin IO, Nesterova SG. 1998. Bryophytes of middle Asia and Kazakhstan. Almaty: GRIDAN. Russian.

Marline L, Andriamiarisoa RL, Bardat J, Chuah-Petiot M, Hedderson TAJ, Reeb C, Strasberg D, Wilding N, Ah-Peng C. 2012. Checklist of the bryophytes of Madagascar. Cryptogamie, Bryologie. 33:199-255. 
Mclntosh T. 2007. Schistidium. In: Flora of North America Editorial Committee, editor. Flora of North America north of Mexico. Vol. 27. Bryophyta, Mosses, part 1. New York (NY): Oxford University Press, p. 207-225.

Medina R, Lara F, Mazimpaka V, Shevock JR, Garilleti R. 2011. Orthotrichum pilosissimum (Orthotrichaceae), a new moss from arid areas of Nevada with unique axillary hairs. The Bryologist. 114:316-324.

Meinunger L, Schröder W. 2007. Verbreitungatlas der Moose Deutschlands. Band 2. Regensburg: Regensburgische Botanische Gesellschaft. German.

Müller F. 2009. An updated checklist of the mosses of Chile. Archive for Bryology. 58:1-124.

Muñoz J. 1999. Revision of Grimmia (Musci, Grimmiaceae) in the Americas. 1: Latin America. Annals of the Missouri Botanical Garden. 86:118-191.

Nosova MB, Novenko EY, Severova EE, Volkova OA. 2019. Vegetation and climate changes within and around the Polistovo-Lovatskaya mire system (Pskov Oblast, northwestern Russia) during the past 10,500 years. Vegetation History and Archaeobotany. 28:123-140.

Ochi H. 1962, 1963. Contributions to the mosses of Bartramiaceae in Japan and the adjacent regions 1, 2. Nova Hedwigia. 4:87-108. Tab. 38-49; 5:91-115, Tab.9-26.

Ochyra R, Bednarek-Ochyra H, Lewis Smith RI. 2002. New and rare moss species from subantarctic South Georgia. Nova Hedwigia. 74:121-147.

Ochyra R, Bednarek-Ochyra H, Lewis Smith Rl. 2008. New and rare moss species from the Antarctic. Nova Hedwigia. 87:457-477.

Ochyra R, Crabtree D, Tangney R. 2015. Studies on mosses in the Falkland Islands: I. Bucklandiella and Codriophorus (Grimmiaceae). Cryptogamie, Bryologie. 36:289-310.

Ochyra R, Lewis Smith RI. 1998. Antarctic species in the genus Ditrichum (Ditrichaceae, Bryopsida), with a description of $D$. gemmiferum sp. nov. Annales Botanici Fennici. 35:33-53.

Ochyra R, Lewis Smith RI, Bednarek-Ochyra H. 2008. The illustrated moss flora of Antarctica. Cambridge: Cambridge University Press.

Ochyra R, Poulsen RS. 2003. Four new moss records from îles Kerguelen. Journal of Bryology. 25:136-137.

Ochyra R, van Rooy J. 2013. Distribution of Bucklandiella lamprocarpa (Grimmiaceae, Musci) in South Africa. Cryptogamie. Bryologie. 34:359-366.

Ochyra R, Zander RH. 2002. The genera Didymodon and Bryoerythrophyllum (Pottiaceae) in the Antarctic. Journal of Bryology. 24:33-44.

Ochyra R, Żarnowiec J, Bednarek-Ochyra H. 2003. Census catalogue of Polish mosses. Kraków: Polish Academy of Sciences, Institute of Botany.

Otnyukova TN, Ignatova EA, Ignatov MS, Fedosov VE. 2004. New records of Tortella alpicola Dix. Eurasia. Arctoa. 13:197-201.

Parnikoza I, Berezkina A, Moiseyenko Y, Malanchuk V, Kunakh V. 2018. Complex survey of the Argentine Islands and Galindez Island (maritime Antarctic) as a research area for studying the dynamics of terrestrial vegetation. Ukrainian Antarctic Journal. 1(17):73-101.

Partyka LYa. 2005. The bryoflora of Crimea. Kyiv: Phytosociocentr. Russian.

Plášek V, Sawicki J, Číhal L. 2014. Orthotrichum pamiricum (Bryophyta), a new epiphytic moss species from Pamir Mountains in Central Asia. Turkish Journal of Botany. 38:754-762.

Podpěra J. 1954. Conspectus muscorum europaeorum. Praha: Nakladatelství Československé Akademie Věd.
Potier de la Varde R. 1955. Mousses récoltées par M. le Dr. Olov Hedberg, en Afrique oreintale, au cours de la mission suédoise de 1948. Arkiv för Botanik. 3:125-204.

Pursell RA. 2007. Fissidentaceae. Flora Neotropica. 101:1-278.

Rams S, Ros RM, Werner O. 2006. Tortella alpicola (Pottiaceae) from Spain, new to Western Europe. The Bryologist. 109:404-407.

Red Data Book of Leningrad Region. 2018. Objects of the plant world. St. Petersburg: Maraphon. Russian.

Red Data Book of Russian Federation. 2008. Plants and Fungi. Moscow: KMK Scientific Press Ltd. Russian.

Red Data Book of St. Petersburg. 2018. St. Petersburg: Diton. Russian.

Reese WD. 2007. Calymperaceae. In: Flora of North America Editorial Committee, editor. Flora of North America north of Mexico. Vol. 27. Bryophyta, Mosses, part 1. New York (NY): Oxford University Press; p. 654-662.

Ros RM, Mazimpaka V, Abou-Salama U, Aleffi M, Blockeel TL, Bregués $M$, Cros RM, Dia MG, Dirkse GM, Draper I, et al. 2013. Mosses of the Mediterranean, an annotated checklist. Cryptogamie, Bryologie. 34:99-283.

Sancho LG, Schulz F, Schroeter B, Kappen L. 1999. Bryophyte and lichen flora of South Bay (Livingston Island: South Shetland Islands, Antarctica). Nova Hedwigia. 68:301-337.

Sawicki J, Plášek V, Ochyra R, Szczecińska $M$, Ślipiko $M$, Myszczyński K, Kulik T. 2017. Mitogenomic analyses support the recent division of the genus Orthotrichum (Orthotrichaceae, Bryophyta). Scientific Reports. 7:4408. doi:10.1038/s41598-017-04833-z.

Sawicki J, Szczecińska M, Bednarek-Ochyra H, Ochyra R. 2015. Mitochondrial phylogenomics supports splitting the traditionally conceived genus Racomitrium (Bryophyta: Grimmiaceae). Nova Hedwigia. 100:293-317.

Schnyder N, Bergamini A, Hofmann H, Müller N, SchubigerBossard C, Urmi E. 2004. Liste Rouge des espèces menacées en Suisse: Bryophytes. In: Office fédéral de l'environnement; editor. L'environnement pratique. No. VU9007-F. Berne.

Schofield WB. 1968. Bryophytes of British Columbia I. Mosses of particular interest. Journal of the Hattori Botanical Laboratory. 31:205-226.

Schröck C, Köckinger H, Amann G, Zechmeister H. 2013. Rote Liste gefährdeter Moose Vorarlbergs. Dornbirn: inaturaErlebnis Naturschau.

Schwarzer C, Joshi J. 2017. Parallel adaptive responses to abiotic but not biotic conditions after cryptic speciation in European peat moss Sphagnum magellanicum Brid. Perspectives in Plant Ecology, Evolution and Systematics. 26:14-27.

Skoupá Z, Ochyra R, Guo S-L, Sulayman M, Plášek V. 2018. Three remarkable additions of Orthotrichum species (Orthotrichaceae) to the moss flora of China. Herzogia. 31:88-100.

Smith A. 2004. The moss flora of Britain and Ireland. 2nd ed. Cambridge: Cambridge University Press.

Sofronova EV, Afonina OM, Akatova TV, Andrejeva EN, Baisheva EZ, Bezgodov AG, Blagovetshenskiy IV, Borovichev EA, Chemeris EV, Chernova AM, et al. 2015. New bryophyte records, 4. Arctoa. 24:224-264.

Ştefănuț S, Goia I. 2012. Checklist and Red List of Bryophytes of Romania. Nova Hedwigia. 95:59-104.

Sukkharak P, Gradstein SR. 2014. A taxonomic revision of the genus Mastigolejeunea (Marchantiophyta: Lejeuneaceae). Nova Hedwigia. 99:279-345.

Swissbryophytes. 2018. Tortella alpicola Dixon. Zürich: Swissbryophytes. [accessed 2020 Jan 1]. https://www.swissbryophytes. ch/index.php/de/verbreitung?taxon_id=nism-4214.

Swissbryophytes. 2019. Nationales Daten- und Informationszentrum der Schweizer Moose [accessed 2019 Oct 3]. www.swissbryophytes.ch. 
Tacchi R, Miserere L, Aleffi M. 2009. Ecological aspects of the bryoflora of some ravines of the Umbro-marchegian Apennines. Plant Biosystems. 143:S88-S96.

Thériot I. 1926. Cinquième contribution a la flore bryologique de Madagascar. Recueil des Publications de la Société Havraise Études Diverses. 92:122-151.

Ulvinen T, Kypärä T. 2009. Nipponinlähdesammal (Philonotis yezoana) Suomen Lapissa. Bryobrotherella. 19:71-76.

Vanderpoorten A, Sotiaux A. 2002. Distribution and ecology of Fissidens celticus J.A.Paton (Fissidentaceae, Bryopsida) in continental Europe. Nova Hedwigia. 74:461-464.

Werner J. 2002. A comparison of Dichodontium flavescens (Dicks.) Lindb. and D. pellucidum (Hedw.) Lindb. Journal of Bryology. 24:215-221.
Wierzgon M, Suchan T, Ronikier M. 2018. Two additions to the moss flora of the South Shetland Islands in the maritime Antarctic. Acta Societatis Botanicorum Poloniae. 87 (4):3598. doi:10.5586/asbp.3598.

Yip KL. 2002. Pseudephemerum, new to the United States and Mexico. The Bryologist. 105:256-258.

Yip KL. 2007. Pseudephemerum. In: Flora of North America Editorial Committee, editor. Flora of North America north of Mexico. Vol. 27. Bryophyta, Mosses, part 1. New York (NY): Oxford University Press; p. 467.

Yousefi N, Hassel K, Flatberg KI, Kemppainen P, Trucchi E, Shaw AJ, Kyrkjeeide MO, Szövényi P, Stenøien HK. 2017. Divergent evolution and niche differentiation within the common peatmoss Sphagnum magellanicum. American Journal of Botany. 104:1060-1072. 